\title{
Exports and inputs of organic carbon on agricultural soils in Germany
}

\author{
Anna Jacobs $\cdot$ Christopher Poeplau $\cdot$ Christian Weiser $\cdot$ Andrea Fahrion-Nitschke • \\ Axel Don
}

Received: 16 January 2020 / Accepted: 28 July 2020/Published online: 8 October 2020

(C) The Author(s) 2020

\begin{abstract}
The quantity and quality of organic carbon $\left(\mathrm{C}_{\text {org }}\right)$ input drive soil $\mathrm{C}_{\text {org }}$ stocks and thus fertility and climate mitigation potential of soils. To estimate fluxes of $\mathrm{C}_{\text {org }}$ as net primary production (NPP), exports, and inputs on German arable and grassland soils, we used field management data surveyed within the Agricultural Soil Inventory $(n=27.404$ cases of sites multiplied by years). Further, we refined the concept of yield-based $\mathrm{C}_{\text {org }}$ allocation coefficients and delivered a new regionalized method applicable for
\end{abstract}

Electronic supplementary material The online version of this article (https://doi.org/10.1007/s10705-020-10087-5) contains supplementary material, which is available to authorized users.

A. Jacobs $(\bowtie) \cdot$ C. Poeplau · C. Weiser .

A. Fahrion-Nitschke $\cdot$ A. Don

Thünen Institute of Climate-Smart Agriculture,

Bundesallee 65, 38116 Brunswick, Germany

e-mail: anna.jacobs@thuenen.de

A. Jacobs

Coordination Unit Soil of Thünen Institute, Bundesallee

49, 38116 Brunswick, Germany

Present Address:

C. Weiser

Fachagentur Nachwachsende Rohstoffe e. V, Hofplatz 1, 18276 Gülzow-Prüzen, Germany

Present Address:

A. Fahrion-Nitschke

Niedersächsische Landesforsten, Forstplanungsamt,

Forstweg 1A, 38302 Wolfenbüttel, Germany agricultural soils in Central Europe. Mean total NPP calculated for arable and grassland soils was $6.9 \pm 2.3$ and $5.9 \pm 2.9 \mathrm{Mg} \mathrm{C}_{\mathrm{org}} \mathrm{ha}^{-1} \mathrm{yr}^{-1}$, respectively, of which approximately half was exported. On average, total $\mathrm{C}_{\text {org }}$ input calculated did not differ between arable $\left(3.7 \pm 1.8 \mathrm{Mg} \mathrm{ha}^{-1} \mathrm{yr}^{-1}\right)$ and grassland soils $\left(3.7 \pm 1.3 \mathrm{Mg} \mathrm{ha}^{-1} \mathrm{yr}^{-1}\right.$ ) but $\mathrm{C}_{\text {org }}$ sources were different: Grasslands received 1.4 times more $\mathrm{C}_{\text {org }}$ from root material than arable soils and we suggest that this difference in quality rather than quantity drives differences in soil $\mathrm{C}_{\text {org }}$ stocks between land use systems. On arable soils, side products were exported in $43 \%$ of the site $*$ years. Cover crops were cultivated in $11 \%$ of site * years and contributed on average $3 \%$ of the mean annual total NPP. Across arable crops, total NPP drove $\mathrm{C}_{\text {org }}$ input $\left(\mathrm{R}^{2}=0.47\right)$ stronger than organic fertilization $\left(\mathrm{R}^{2}=0.11\right)$. Thus, maximizing plant growth enhances $\mathrm{C}_{\text {org }}$ input to soil. Our results are reliable estimates of management related $\mathrm{C}_{\text {org }}$ fluxes on agricultural soils in Germany.

Keywords Carbon sequestration - Manure $\cdot$ Net primary productivity $\cdot$ Carbon balance $\cdot$ Net biome productivity

\section{Introduction}

The content or stock of soil organic carbon (SOC) in agricultural soils is regarded as the key parameter 
sustaining soil fertility and health. Moreover, the carbon (C) cycle of agricultural systems plays a role in climate change mitigation: since the more $\mathrm{C}$ is stored as organic $\mathrm{C}\left(\mathrm{C}_{\text {org }}\right)$ in the soil and the longer it is stored for, the less it contributes to climate change as the major greenhouse gas $\mathrm{CO}_{2}$ (Minasny et al. 2017). It is widely acknowledged that farming practices can influence SOC levels to a certain extent (Freibauer et al. 2004). On field scale, SOC stocks are strongly correlated with the amount of $\mathrm{C}_{\text {org }}$ input, which is the almost exclusive source of SOC (Kätterer et al. 2012). However, on a national scale, there are very few data available on the amount of $\mathrm{C}_{\text {org }}$ input to agricultural soils.

The quantity, and also the quality, of organic inputs play an important role in SOC build-up and dynamics. For example, recent studies suggested that root- and manure-derived $\mathrm{C}_{\text {org }}$ has stronger effects on SOC stocks than straw-derived $\mathrm{C}_{\text {org }}$ (Kätterer et al. 2011; Rasse et al. 2005). Both the quantity and quality (e.g. $\mathrm{C}_{\text {org }}$ to nitrogen ratio of organic material) of $\mathrm{C}_{\text {org }}$ input to soil are controlled by the farmer through the choice of crop rotation, amount and type of mineral and organic fertilizers applied, and harvest residue management. The farmer also determines total net primary production ( $\mathrm{NPP}_{\text {tot }} ; \mathrm{Mg} \mathrm{C}_{\mathrm{org}} \mathrm{ha}^{-1} \mathrm{yr}^{-1}$ ), the fraction of NPP that is harvested as the main product, and the amount of $\mathrm{C}_{\text {org }}$ ultimately returned to the soil. There are five main pathways of $\mathrm{C}_{\text {org }}$ input to agricultural soils, governed by: (1) type and amount of aboveground harvest residues if left in the field, stubbles always remaining in the field or mulch if left in the field, (2) type and amount of organic fertilizers applied, (3) type and amount of excreta produced by grazing animals, (4) cover crops used for green manure, and (5) belowground biomass as dead roots and rhizodeposition. This implies that agricultural soils have C-sink potential and that implementation of certain management practices could help mitigate climate change (Minasny et al. 2017).

To understand, predict, and report SOC stock changes in agricultural systems, information on management and related $\mathrm{C}_{\text {org }}$ fluxes from and to the soil is of critical importance. In addition, knowledge on the regional distribution of harvest exports and inputs of $\mathrm{C}_{\text {org }}$ to soil is required for development of climatesmart and sustainable solutions in agriculture. However, field-specific data are often not available at national scales preventing ' $\mathrm{C}_{\mathrm{org}}$ management' from being closely linked to SOC dynamics. The absolute magnitude of the major management-related annual fluxes of $\mathrm{C}_{\text {org }}$ on agricultural soils, i.e. $\mathrm{NPP}_{\text {tot }}, \mathrm{C}_{\text {org }}$ export from the site, and $\mathrm{C}_{\text {org }}$ input from external sources are generally not well quantified. Estimates of $\mathrm{C}_{\text {org }}$ input to soil, e.g. when modeling SOC dynamics within the context of greenhouse gas reporting, are thus often derived from national or regional agricultural yield statistics (Andren et al. 2008). These statistics are than combined with plant-specific harvest indices and $\mathrm{C}_{\text {org }}$ allocation coefficients which are published for the major crops, forages (wheat, barley, oat, triticale, oil seed rape, grain maize, silage maize, potato, sugar beet, mustard, some legumes) and grasslands (Bolinder et al. 2007, 2015; Gan et al. 2009). Manure application rates can be roughly estimated from the number of animals reported in a specific region, while harvest residue management is not given in agricultural yield statistics. However, residue management is somewhat important for $\mathrm{C}_{\text {org }}$ input to soil since some harvest residues are removed from the field, e.g., for bioenergy provision and some are left in situ.

Apart from obvious uncertainties in agricultural activity data, another major source of uncertainty is the use of $\mathrm{C}_{\text {org }}$ allocation coefficients and harvest indices derived from global reviews. However, $\mathrm{C}_{\text {org }}$ allocation coefficients are needed to convert yield data into root- and shoot-derived $\mathrm{C}_{\text {org }}$ input. Keel et al. (2017) and Riggers et al. (2019) demonstrated that the choice of allocation coefficients used for $\mathrm{C}_{\text {org }}$ input estimation strongly influences the SOC trends modeled. Region-specific up-to-date allocation coefficients and harvest indices are required to minimize this source of error. So far, region-specific allocation coefficients are not applied for estimates of $\mathrm{C}_{\text {org }}$ input although validated values for, e.g., crop-specific harvest indices are available.

The specific aims of this study were to

(1) establish a sound method for estimation of mean annual $\mathrm{NPP}_{\text {tot }}, \mathrm{C}_{\text {org }}$ inputs, and $\mathrm{C}_{\text {org }}$ exports from arable and grassland sites under Central European environmental conditions.

(2) quantify and compare mean annual $\mathrm{NPP}_{\text {tot }}, \mathrm{C}_{\text {org }}$ inputs and $\mathrm{C}_{\text {org }}$ exports across land use systems in Germany.

(3) determine the spatial distribution of $\mathrm{C}_{\text {org }}$ input and its sources in Germany. 
Data from the first German Agricultural Soil Inventory were used in the analysis. These comprised 10 years of management data, including crop type, yield, fertilization practices, harvest residue management, field operations, and other key variables such as livestock density, for each of 3104 arable and grassland sites surveyed within the Agricultural Soil Inventory. Based on this 'first-hand' dataset and on regional harvest indices, we estimated $\mathrm{NPP}_{\text {tot }}$ on arable and grassland sites, total $\mathrm{C}_{\text {org }}$ export via harvest of main products, and sources of $\mathrm{C}_{\text {org }}$ input across Germany.

\section{Materials and methods}

Database of agronomic and grassland management

The German Agricultural Soil Inventory collected samples of soils under agricultural land use in a $8 \mathrm{~km} \times 8 \mathrm{~km}$ grid across Germany (Jacobs et al. 2018) accompanied by collection of arable and permanent grassland management data through a questionnaire sent to the farmers on whose sites soil sampling was performed. Thereby, for the definition of 'permanent grassland' (referred to as 'grassland' in the following), we referred to the one used in agricultural practice where a grassland is permanent after five years of continuous grassland use. Farmers were asked to record type of crop rotation, fresh matter yield of the main product, harvest residues management regimes, cover crops management regimes, and the amount and type of organic fertilizers used. For grassland sites, farmers were asked to record dry matter yield, number of cuts per year, mulching, amount and type of organic fertilizers used, and number and species of grazing animals. If possible, farmers were supposed to deliver the respective data on the previous decade of management, if possible. However, in the present analysis, we had to exclude some records (site * years) from the data set due to incomplete information especially on (1) crops and cover crops indicated as 'unknown' or 'unspecified' ( $\mathrm{n}=79$ and 247, respectively), (2) data entries with no information on harvest residues management $(n=485)$, (3) data entries on use of organic fertilizer that did not state the amount or type $(n=45)$, and (4) data entries on pastures with no information on grazing animals or farm's livestock $(n=631)$. This left 2097 arable sites and 718 grassland sites for the evaluation. These values were multiplied by the site-specific management years, and thus a total of 19,987 arable site * years and 7417 grassland site * years in the period 2001-2016 were evaluated as cases in the present study. If not stated otherwise, results are shown as mean of site * years.

Method's development: Organic carbon allocation coefficients for arable crops grown under Central European conditions

Based on crop-specific harvest indices and on a set of coefficients of $\mathrm{C}_{\text {org }}$ allocation among crop compartments taken from the literature, we derived $\mathrm{C}_{\text {org }}$ allocation factors specific for cultivation conditions in Central Europe in order to estimate annual $\mathrm{C}_{\text {org }}$ input $\left(\mathrm{Mg} \mathrm{C}_{\text {org }} \mathrm{ha}^{-1} \mathrm{yr}^{-1}\right)$ to soil based on yield information. The concept of $\mathrm{C}_{\text {org }}$ allocation, as described in detail by Bolinder et al. (2007), is based on the assumption that the sum of $\mathrm{C}_{\text {org }}$ within all plant compartments equals $\mathrm{NPP}_{\text {tot }}\left(\mathrm{Mg} \mathrm{C}_{\text {org }} \mathrm{ha}^{-1} \mathrm{yr}^{-1}\right)$ and that all $\mathrm{C}_{\text {org }}$ allocation factors add up to 1 .

For arable crops, we applied the following five, crop-specific $\mathrm{C}_{\text {org }}$ allocation factors $\left(\mathrm{CA}_{\mathrm{x}}\right)$ :

$\mathrm{CA}_{\mathrm{MP}}+\mathrm{CA}_{\mathrm{HR}}+\mathrm{CA}_{\mathrm{ST}}+\mathrm{CA}_{\mathrm{R}}+\mathrm{CA}_{\mathrm{RD}}=1$

where MP is the main product, HR is the harvest residues, $\mathrm{ST}$ is stubbles as the part of HR always remaining in the field, $R$ is dead roots, and $R D$ is rhizodeposition.

We calculated the $\mathrm{C}_{\text {org }}$ allocation factors for arable main products, harvest residues, and stubbles based on $\mathrm{C}_{\text {org }}$ content, dry matter content, harvest index, and a stubble index for arable crops obtained in a literature search prioritizing German references (Table 1). The selection criteria for the search were, in descending order: (1) agricultural management representative of commercial farming in Germany, (2) factors quotable, and (3) factors consistent with each other. We generally took the mean value when more than one value was available. There are generally no data available specifically for cultivars used in organic agriculture although it is known that the physiology, and thus $\mathrm{C}_{\text {org }}$ allocation, of these cultivars differs from that of cultivars used in conventional agriculture. In this study, only $5 \%$ of the arable sites evaluated were under organic management and we ignored this 


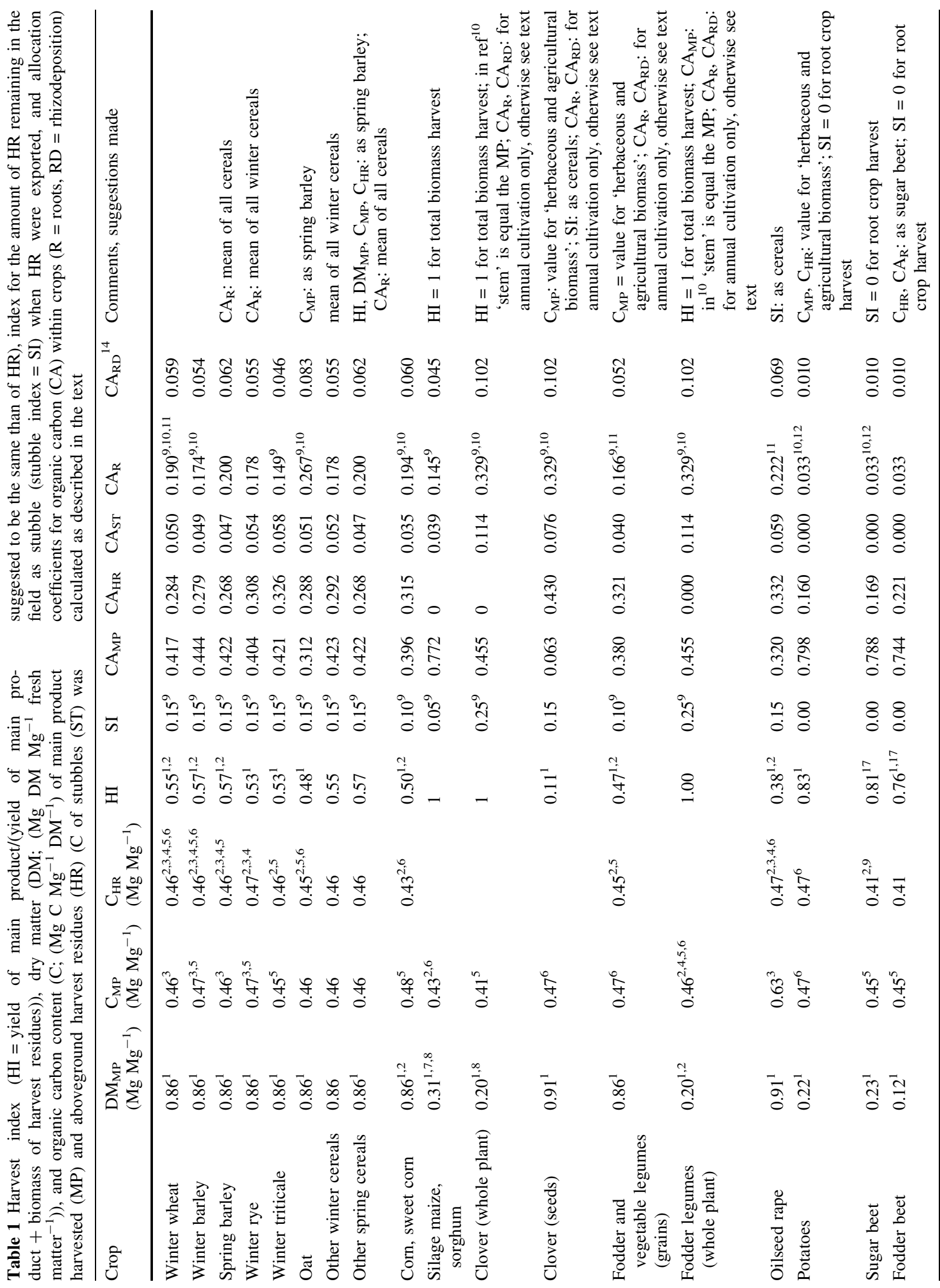




\begin{tabular}{|c|c|c|c|c|c|c|c|c|c|}
\hline 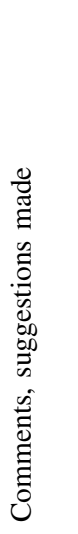 & 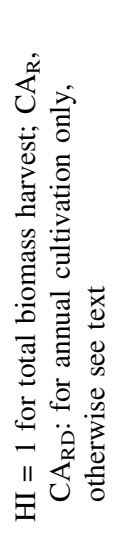 & 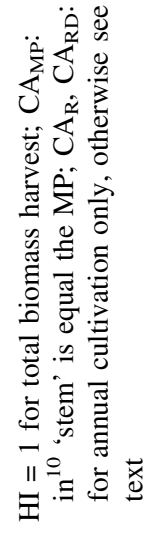 & 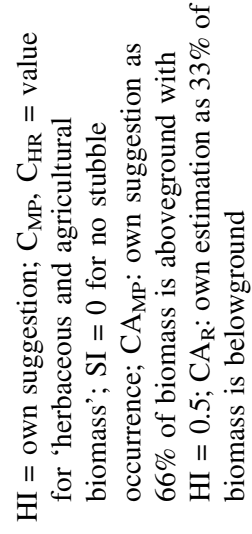 & 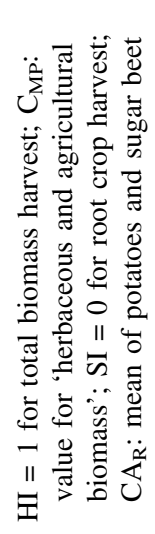 & 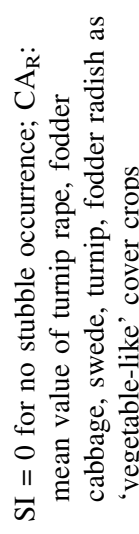 & 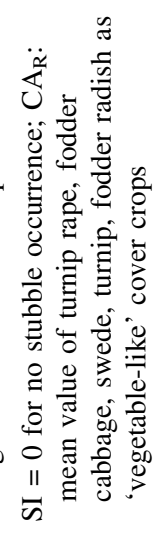 & 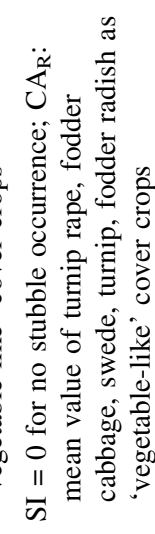 & 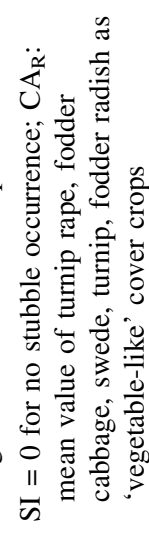 & 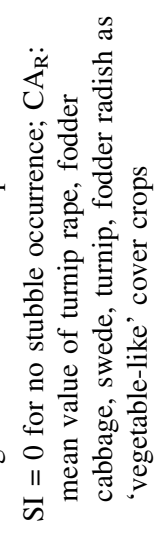 \\
\hline 产 & $\frac{4}{\stackrel{4}{0}}$ & ô. & ठั. & $\stackrel{0}{\circ}$ & 芯 & 芯 & Sิ & ¿̂. & 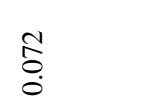 \\
\hline 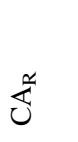 & \begin{tabular}{l}
$\infty$ \\
$\infty$ \\
\multirow{+}{+}{} \\
0
\end{tabular} & $\begin{array}{l}\stackrel{0}{0} \\
\text { ì } \\
\text { ते }\end{array}$ & ర్లి & है & 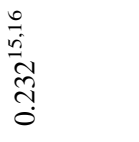 & 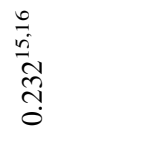 & 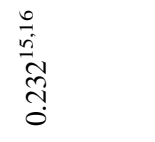 & $\begin{array}{l}\frac{0}{n} \\
\stackrel{n}{\sim} \\
\tilde{n} \\
0\end{array}$ & 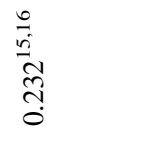 \\
\hline 㺼 & $\begin{array}{l}n \\
\stackrel{n}{0} \\
0\end{array}$ & $\stackrel{0}{\circ}$ & $\stackrel{8}{8}$ & $\stackrel{8}{8}$ & $\stackrel{8}{8}$ & $\stackrel{8}{8}$ & 8 & $\stackrel{8}{8}$ & 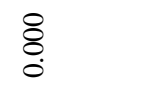 \\
\hline 苞 & $\stackrel{8}{0}$ & $\stackrel{8}{8}$ & రి & $\stackrel{8}{\circ}$ & 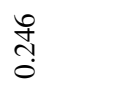 & 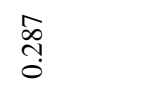 & $\frac{8}{0}$ & 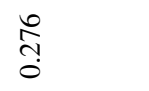 & 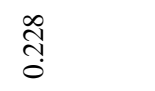 \\
\hline 节 & $\begin{array}{l}\text { Oे } \\
0 \\
0\end{array}$ & $\tilde{n}$ & $\begin{array}{l}1 \\
\text { రิ } \\
\text { ô }\end{array}$ & $\hat{n}$ & 官 & ò & $\begin{array}{l}0 \\
n \\
n \\
0\end{array}$ & $\stackrel{\widetilde{গ}}{\stackrel{0}{0}}$ & $\stackrel{\infty}{o}$ \\
\hline $\bar{n}$ & $\frac{\text { in }}{0}$ & in & 0 & 0 & 0 & 0 & 0 & 0 & 0 \\
\hline 国 & - & - & $\stackrel{n}{n}$ & - & $\stackrel{m}{\circ}$ & $\stackrel{m}{\Delta}$ & $\frac{m}{\stackrel{0}{0}}$ & $\begin{array}{l}\text { mon } \\
\stackrel{0}{0} \\
0\end{array}$ & $\stackrel{m}{\widehat{m}}$ \\
\hline 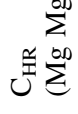 & & & $\stackrel{\stackrel{0}{+}}{\stackrel{5}{0}}$ & & $\stackrel{\sim}{\tilde{\sigma}}$ & $\stackrel{\sim}{f}$ & $\stackrel{\tilde{F}}{\stackrel{0}{0}}$ & $\stackrel{\sim}{\stackrel{n}{\sigma}}$ & $\stackrel{\mathscr{O}}{\tilde{\sigma}}$ \\
\hline$\underbrace{\frac{\sum_{0}^{\infty}}{\sum^{\infty}} \sum^{\infty}}$ & ْ̊o & 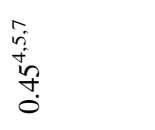 & 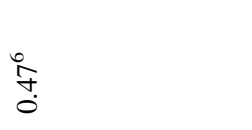 & 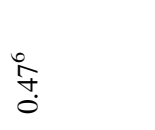 & $\stackrel{n}{n}$ & $\tilde{n}$ & $\bar{n}$ & $\stackrel{n}{n}$ & $\bar{n}$ \\
\hline$\sum_{i}^{\infty} \sum_{i}^{\infty} \sum^{\infty}$ & 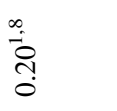 & त्) & $\stackrel{\infty}{\circ}$ & $\stackrel{\infty}{\stackrel{\infty}{0}}$ & $\stackrel{m}{0}$ & $\stackrel{m}{0}$ & $\stackrel{m}{0}$ & $\stackrel{m}{0}$ & $\stackrel{m}{0}$ \\
\hline 家 & 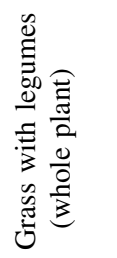 & 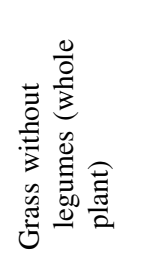 & 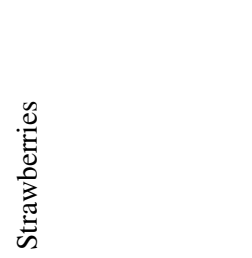 & 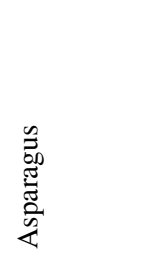 & 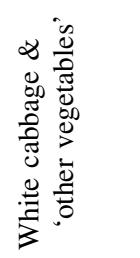 & 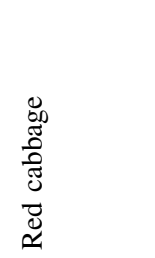 & 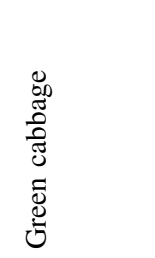 & 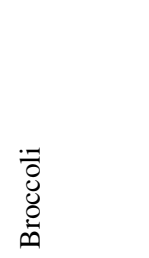 & 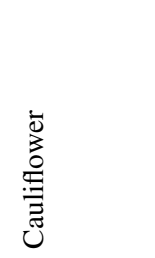 \\
\hline
\end{tabular}




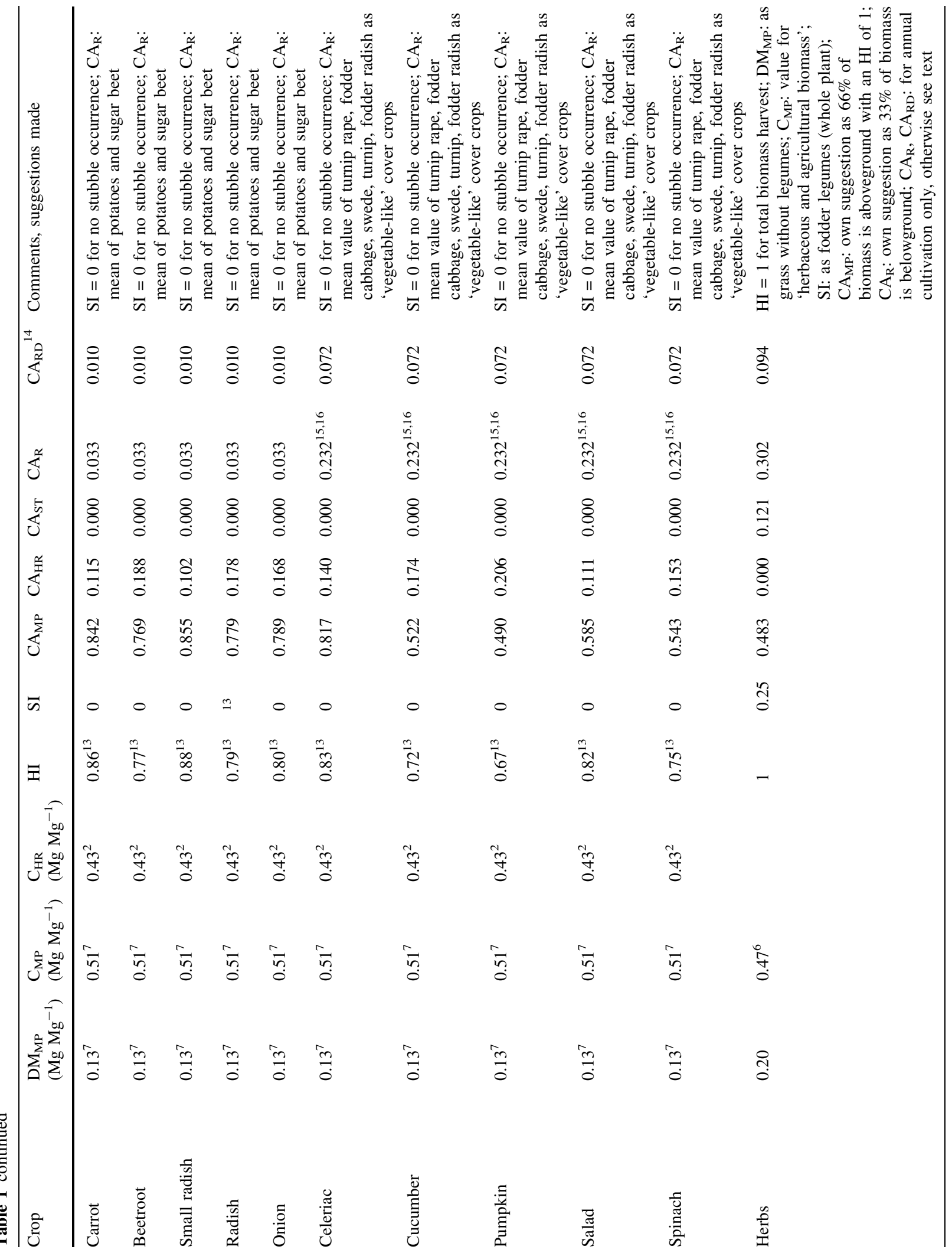




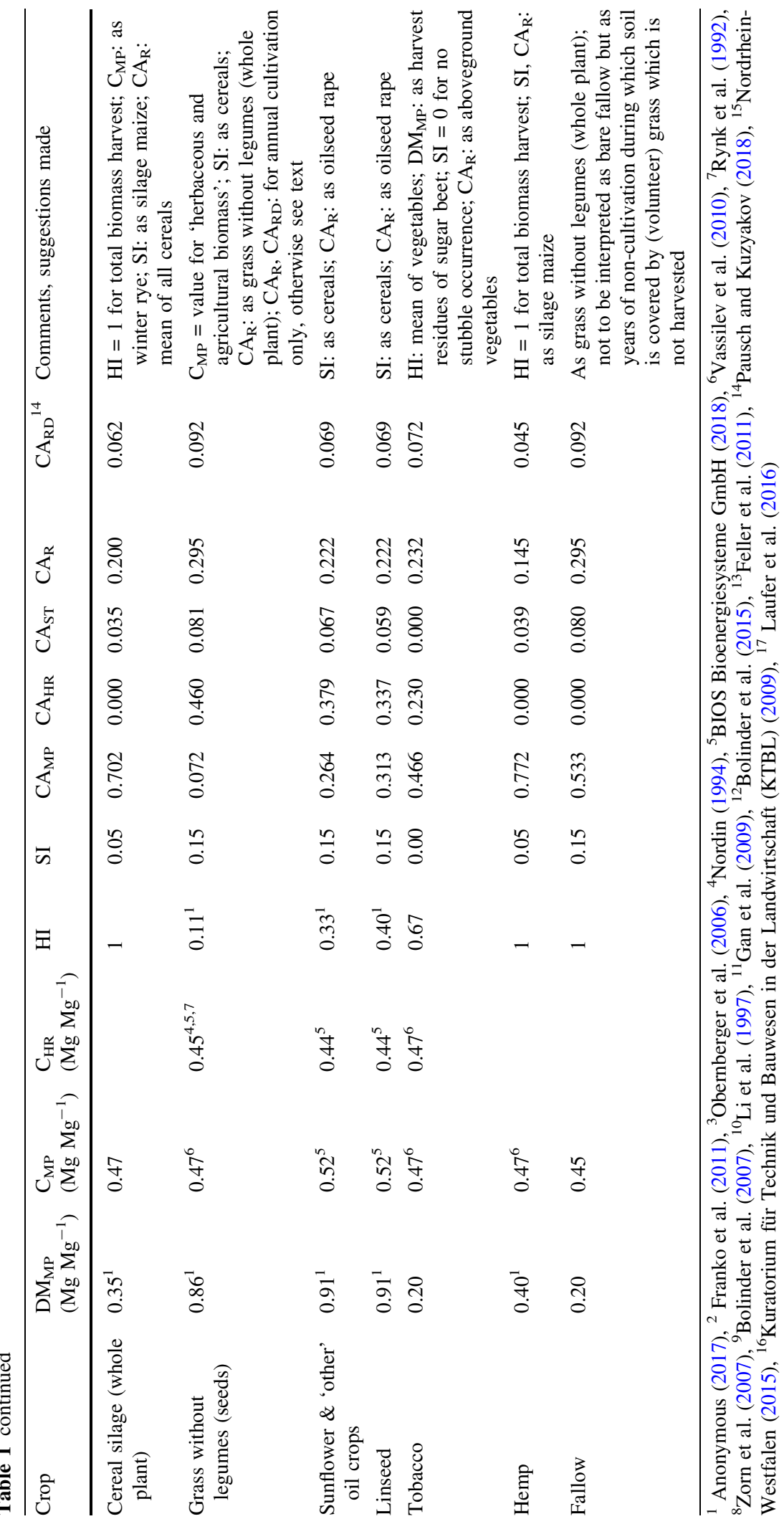


circumstance and applied the mean values we found to all records.

The $\mathrm{C}_{\text {org }}$ allocation factor of the main product $\left(\mathrm{CA}_{\mathrm{MP}}\right)$ was calculated as:

$C A_{M P}=\frac{A-M P * D M_{M P} * C_{M P}}{N P P_{\text {tot }}}$

where A-MP is the fresh matter yield of the main product of an arable crop $\left(\mathrm{Mg} \mathrm{ha}^{-1} \mathrm{yr}^{-1}\right), \mathrm{DM}_{\mathrm{MP}}$ is its dry matter content $\left(\mathrm{Mg} \mathrm{Mg}^{-1}\right), \mathrm{C}_{\mathrm{MP}}$ is the $\mathrm{C}_{\text {org }}$ content $\left(\mathrm{Mg} \mathrm{Mg}^{-1}\right.$ dry matter $\left.{ }^{-1}\right)$ (Table 1$)$, and $\mathrm{NPP}_{\text {tot }}(\mathrm{Mg}$ $\mathrm{C}_{\mathrm{org}} \mathrm{ha}^{-1} \mathrm{yr}^{-1}$ ) was calculated as described below.

The $\mathrm{C}_{\text {org }}$ allocation factor of harvest residues $\left(\mathrm{CA}_{\mathrm{HR}}\right)$ was calculated as:

$C A_{H R}=\frac{A-M P * \frac{D M_{M P}}{H I} *(1-H I) * C_{H R} *(1-S I)}{N P P_{t o t}}$

where A-MP is the fresh matter yield of the MP of an arable crop $\left(\mathrm{Mg} \mathrm{ha}^{-1} \mathrm{yr}^{-1}\right), \mathrm{DM}_{\mathrm{MP}}$ is its dry matter content $\left(\mathrm{Mg} \mathrm{Mg}^{-1}\right), \mathrm{HI}$ is the harvest index, $\mathrm{C}_{\mathrm{HR}}$ is the $\mathrm{C}_{\text {org }}$ content of harvest residues $\left(\mathrm{Mg} \mathrm{Mg}^{-1}\right.$ dry matter ${ }^{-1}$ ), SI is the stubble index as the proportion of HR always remaining in the field as stubbles and therefore supposed to be calculated as a separate compartment of the crop (for crops for which MP is total aboveground biomass harvested, it is a proportion of MP) (Table 1), and NPP tot $\left(\mathrm{Mg} \mathrm{C}_{\text {org }}\right.$ ha $\left.^{-1} \mathrm{yr}^{-1}\right)$ was calculated as described below.

The $\mathrm{C}_{\text {org }}$ allocation factor for stubbles $\left(\mathrm{CA}_{\mathrm{ST}}\right)$ was calculated as:

$C A_{S T}=\frac{A-M P * \frac{D M_{M P}}{H I}(1-H I) * S I * C_{H R}}{N P P_{t o t}}$

where A-MP is the fresh matter yield of the main product of an arable crop $\left(\mathrm{Mg} \mathrm{ha}^{-1} \mathrm{yr}^{-1}\right), \mathrm{DM}_{\mathrm{MP}}$ is its dry matter content $\left(\mathrm{Mg} \mathrm{Mg}^{-1}\right)$, $\mathrm{HI}$ is the harvest index, $\mathrm{C}_{\mathrm{HR}}$ is the $\mathrm{C}_{\mathrm{org}}$ content of the harvest residues $\left(\mathrm{Mg} \mathrm{Mg}^{-1}\right.$ dry matter $\left.{ }^{-1}\right)$, SI is the stubble index assuming that stubbles have the same $\mathrm{C}_{\text {org }}$ content as harvest residues (Table 1); $\mathrm{NPP}_{\text {tot }}\left(\mathrm{Mg} \mathrm{C}_{\text {org }}\right.$ ha $\left.^{-1} \mathrm{yr}^{-1}\right)$ was calculated as described below.

To develop the $\mathrm{C}_{\text {org }}$ allocation factor for roots, we used crop-specific constant ratios of aboveground NPP $\left(\mathrm{NPP}_{\text {above }}\right)$ to belowground NPP $\left(\mathrm{NPP}_{\text {below }}\right)$ allocation empirically derived from different studies following the general concept of $\mathrm{C}_{\text {org }}$ allocation (Table 1). We applied the $\mathrm{NPP}_{\text {above }}$ : NPP below ratio to $\mathrm{NPP}_{\text {above }}$ (see below) although there are recent findings that at least wheat has rather a fixed than a yield-dependent $\mathrm{NPP}_{\text {below }}$ (Taghizadeh-Toosi et al. 2016). However, these results were not proven for the broad spectra of arable crops we evaluated here and thus we used the conventional concept of $\mathrm{C}_{\text {org }}$ allocation based on findings of Bolinder et al. (2007).

To derive the $\mathrm{C}_{\text {org }}$ allocation factor for rhizodeposition, we used a recent values published in a review by Pausch and Kuzyakov (2018) who concluded that rhizodeposition is $0.31 *$ root- $\mathrm{C}_{\text {org }}$ for most arable crops. The term rhizodeposition as used here is equal to the net rhizodeposition defined by Pausch and Kuzyakov (2018) as the part of $\mathrm{C}_{\text {org }}$ remaining longer in soil since it is not mineralized by soil organisms immediately after being released into the soil.

Calculation of annual net primary production on arable sites

For arable crops, calculations of annual $\mathrm{NPP}_{\text {tot }}(\mathrm{Mg}$ $\mathrm{C}_{\text {org }} \mathrm{ha}^{-1} \mathrm{yr}^{-1}$ ) for each site * year was based on the fresh matter yield of the respective main product, which in most cases $(79 \%$ of site * years evaluated) was recorded by the farmer. Missing values were replaced as accurately as possible by statistical values in a three-step procedure: (1) If available, the yearspecific yield of the main product at site-specific NUTS3 level (Landkreis) was used; (2) otherwise, the year-specific mean value of the respective Federal State was used; (3) if still not available, a statistical mean of Germany was used or a rough estimate was made (Graf et al. 2005; Kuratrorium für Technik und Bauwesen in der Landwirtschaft (KTBL) 2009; Landwirtschaftskammer Niedersachsen 2007, 2014, Statistisches Bundesamt (Destatis) 2003-2018, Technologie- und Förderzentrum (TFZ) im Kompetenzzentrum Nachwachsende Rohstoffe 2007). The statistical values of yield of the main product were adjusted to the yield level of the specific farm: For each farm and crop, a 'recorded:statistical' factor was calculated when the respective yield was recorded at least for 2 years; otherwise, the factor was calculated as the mean factor across all crops recorded. If no records were available, no adjustment was made.

If a record indicated that an arable crop was not harvested and all biomass was tilled into the soil, as done for fallow (unharvested grass; $3 \%$ of the site * years evaluated) or after extreme weather events 
$(0.3 \%$ of the site $*$ years evaluated $)$, the yield of the main product was set as zero. However, in further calculations, e.g. $\mathrm{NPP}_{\text {above }}$, we needed an equivalent to the potential yield and estimated it as being about $50 \%$ of a default fresh matter yield (own suggestions as a rough estimate based on Graf et al. 2005; Kuratrorium für Technik und Bauwesen in der Landwirtschaft (KTBL) 2009; Landwirtschaftskammer Niedersachsen 2007, 2014; Statistisches Bundesamt (Destatis) 2003-2018; Technologie- und Förderzentrum (TFZ) im Kompetenzzentrum Nachwachsende Rohstoffe 2007): fallow: $15 \mathrm{Mg}$ fresh matter $\mathrm{ha}^{-1}$, grass: $15 \mathrm{Mg}$ fresh matter $\mathrm{ha}^{-1}$, winter rye: $2.5 \mathrm{Mg}$ fresh matter $\mathrm{ha}^{-1}$, clover (whole plant): $17.5 \mathrm{Mg}$ fresh matter $\mathrm{ha}^{-1}$, grass with legumes (whole plant): 17.5 $\mathrm{Mg}$ fresh matter $\mathrm{ha}^{-1}$, fodder legumes (whole plant): $17.5 \mathrm{Mg}$ fresh matter ha ${ }^{-1}$, winter wheat: $4 \mathrm{Mg}$ fresh matter $\mathrm{ha}^{-1}$, fodder legumes (grains): $1.5 \mathrm{Mg}$ fresh matter ha ${ }^{-1}$, grass without legumes (grains): 0.5 fresh matter $\mathrm{Mg} \mathrm{ha}^{-1}$, winter oilseed rape: $18 \mathrm{Mg}$ fresh matter ha ${ }^{-1}$.

On arable sites, $\mathrm{NPP}_{\text {tot }}$ comprised all aboveground and belowground biomass compartments of the main crop and the cover crop. For perennial cultivation of grass, legumes, and herbs, NPP below was calculated as for permanent grasslands (see below) except in the last year of the cultivation period. For cover crops, yield and belowground biomass were not recorded, and were thus estimated based on a literature search and a default $\mathrm{C}_{\text {org }}$ content of $0.47 \mathrm{Mg} \mathrm{Mg}^{-1}$ dry matter ${ }^{-1}$ ('herbaceous and agricultural biomass' in Vassilev et al. (2010)) to obtain $\mathrm{NPP}_{\text {above }}$ and $\mathrm{NPP}_{\text {below }}$ for cover crops (Table S1). Rhizodeposition by cover crops was set at $0.31 *$ root- $\mathrm{C}_{\text {org }}$ (Pausch and Kuzyakov 2018).

The annual $\mathrm{NPP}_{\text {tot }}\left(\mathrm{Mg} \mathrm{C}_{\text {org }} \mathrm{ha}^{-1} \mathrm{yr}^{-1}\right)$ on arable sites $\left(\mathrm{A}-\mathrm{NPP}_{\text {tot }}\right)$ was calculated as the sum of $\mathrm{NPP}_{\text {above }}$ and $\mathrm{NPP}_{\text {below }}$ of the main product and the cover crop (CC-) (Eq. 5). For A-NPP above and A-NPP below, $\mathrm{C}_{\text {org }}$ allocation factors were applied to the fresh matter yield (Eqs. 6, 7).:

$$
\begin{aligned}
A-N P P_{\text {tot }}= & A-N P P_{\text {above }}+A-N P P_{\text {below }} \\
& +C C-N P P_{\text {above }}+C C-N P P_{\text {below }}
\end{aligned}
$$

$$
\begin{aligned}
A-N P P_{\text {above }}= & \left(A-M P * D M_{M P} * C_{M P}\right) \\
& +\left(A-M P * D M_{M P} * \frac{C_{M P}}{C A_{M P}} * C A_{H R}\right) \\
& +\left(A-M P * D M_{M P} * \frac{C_{M P}}{C A_{M P}} * C A_{S T}\right)
\end{aligned}
$$

$$
\begin{aligned}
A-N P P_{\text {below }}= & \left(A-M P * D M_{M P} * \frac{C_{M P}}{C A_{M P}} * C A_{R}\right) \\
& +\left(A-M P * D M_{M P} * \frac{C_{M P}}{C A_{M P}} * C A_{R D}\right)
\end{aligned}
$$

where A-MP is the fresh matter yield of the main product of an arable crop $\left(\mathrm{Mg} \mathrm{ha}^{-1} \mathrm{yr}^{-1}\right), \mathrm{DM}_{\mathrm{MP}}$ is its dry matter content $\left(\mathrm{Mg} \mathrm{Mg}^{-1}\right), \mathrm{C}_{\mathrm{MP}}$ is its $\mathrm{C}_{\mathrm{org}}$ content $\left(\mathrm{Mg} \mathrm{Mg}^{-1}\right.$ dry matter $\left.{ }^{-1}\right), \mathrm{CA}_{\mathrm{MP}}$ is the $\mathrm{C}_{\text {org }}$ allocation factor of the main product, $\mathrm{CA}_{\mathrm{HR}}$ is the $\mathrm{C}_{\mathrm{org}}$ allocation factor of the harvest residues, $\mathrm{CA}_{\mathrm{ST}}$ is the $\mathrm{C}_{\mathrm{org}}$ allocation factor of the stubbles, $\mathrm{C}_{\mathrm{AR}}$ is the $\mathrm{C}_{\mathrm{org}}$ allocation factor of the roots, and $\mathrm{CA}_{\mathrm{RD}}$ is the $\mathrm{C}_{\mathrm{org}}$ allocation factor of the rhizodeposition (Table 1).

Calculation of annual net primary production of grassland sites

For grassland sites, annual $\mathrm{NPP}_{\text {tot }}\left(\mathrm{Mg} \mathrm{C}_{\text {org }} \mathrm{ha}^{-1} \mathrm{yr}^{-1}\right)$ was again based on the 'yield', which was also recorded in the questionnaire. Three different types of grassland were distinguished and we developed specific approaches to fill gaps in yield data and to estimate $\mathrm{NPP}_{\text {above }}$ for these grassland types: meadows (grassland mown), pastures (grassland grazed) and mown pastures (grassland grazed and mown).

Missing yield data for meadows (42\% of site * years recorded) were replaced with statistical values, in the same way as for arable crops, to derive the amount of biomass exported. However, for meadows, the average values obtained from NUTS3 statistics did not distinguish between different management intensities. The biomass exported from meadows is correlated to the number of cuts per year which is also an indicator for management intensity. Wendland et al. (2018), representing the agricultural extension service in Bavaria, published a linear relationship $\left(y=16.2+25 ; R^{2}=0.99\right)$ for intensively managed meadows for the use of official fertilization recommendations. Based on these long term experiences, we 
adjusted the statistical values as follows: We assumed that the statistical grassland yield values reflect a common number of cuts, which we set equal to the country-wide average number of cuts (2.66) recorded in the Agricultural Soil Inventory database. We then adjusted the statistical grassland main product by the number of cuts recorded using specific factors (Table S2), based on a linear relationship between yield and number of cuts derived from field observation (Wendland et al. 2018). Thus, for meadows with two or fewer cuts, we reduced the statistical yield, while for meadows with of three or more cuts we increased it.

For pastures, yield data recorded were assumed to be an estimate of total uptake by grazing animals, which we refer to as grassland main product taken-up. When no yield for pastures was recorded, biomass uptake was calculated from recorded livestock units grazing on the site and mean biomass uptake values for all cattle specimen used in the German National Inventory Report (Rösemann et al. 2017). This was the case for $23 \%$ of all site * years recorded for pastures. Missing data on livestock units grazing were replaced by dividing the number, species, and days of animals grazing recorded for the entire farm by the total pasture area recorded for the farm. This was the case for $71 \%$ of all site * years recorded for pastures. The major assumption in this approach was that grazing animals were equally distributed over the total pasture area of the farm. Default values used to calculate species-specific grassland main product taken up are given in Table $\mathrm{S} 3$.

For mown pastures, the yield recorded was divided into main product yield and biomass taken up in the following way and as a rough approximation (for details, see Table S4): If one cut was performed, it accounted for $25 \%$ of the total yield, two cuts accounted for $50 \%$, and more than two cuts accounted for $75 \%$ of the yield, while the rest was assigned to biomass taken up. When the yield was not recorded for mown pastures, we calculated the biomass taken up as described for pastures and multiplied the number of cuts recorded by $1.7 \mathrm{Mg}$ dry matter $\mathrm{ha}^{-1}$ as the best estimate of yield, based on the equation given above. This was the case for $38 \%$ of the records evaluated for pastures.

If not stated otherwise, we assumed that a record indicating mulching was one cut of $1.7 \mathrm{Mg}$ dry matter $\mathrm{ha}^{-1}$ remaining in the field.
The calculation of annual $\mathrm{NPP}_{\text {above }}$ on grassland sites (G-NPP ${ }_{\text {above }} ; \mathrm{Mg} \mathrm{C}_{\text {org }} \mathrm{ha}^{-1} \mathrm{yr}^{-1}$ ) was the sum of all grassland biomass grown on the site (for exact calculation, see Table S4):

$$
\begin{aligned}
G-N P P_{\text {above }}= & \left(G-M P+G-M P_{u p}+M U\right) * 1.215 \\
& * 0.45
\end{aligned}
$$

where G-MP is the dry matter yield of the main product of the grassland site $\left(\mathrm{Mg} \mathrm{ha}^{-1} \mathrm{yr}^{-1}\right), \mathrm{G}_{-} \mathrm{MP}_{\mathrm{up}}$ is the biomass taken up by animals $\left(\mathrm{Mg} \mathrm{ha}^{-1} \mathrm{yr}^{-1}\right)$, MU is the biomass mulched $\left(\mathrm{Mg} \mathrm{ha}^{-1} \mathrm{yr}^{-1}\right)$, the factor 1.215 represents the part of biomass that grows each year after the last cut or before/after grazing period of animals which is about $30 \%$ of the biomass measured as G-MP or G-MP up $_{\text {or }}$ MU (Christensen et al. 2009) and of which 50\% decays within the year evaluated (Poeplau 2016), and 0.45 is the $\mathrm{C}_{\text {org }}$ content $\left(\mathrm{Mg} \mathrm{Mg}^{-1}\right.$ dry matter $^{-1}$ ) of the aboveground biomass (Bolinder et al. 2007).

Grassland specimen were lately proven to be extremely variable in the ratio of $\mathrm{NPP}_{\mathrm{above}}$ to $\mathrm{NPP}_{\mathrm{be}}$ low (also known as 'root:shoot ratio') with increasing values due to management intensity, especially due to fertilization (Ammann et al. 2009; Cong et al. 2019; Poeplau 2016; Sochorová et al. 2016). Meanwhile, the studies cited showed that belowground biomass of grassland specimen was rather unaffected by management. In accordance to that, an earlier study (Poeplau et al. 2018), in which seven different long-term fertilized grassland experiments in Germany were sampled, we statistically proved that $\mathrm{NPP}_{\text {below }}$ was unaffected by fertilization and site. The average root$\mathrm{C}_{\text {org }}$ stock to a depth of $100 \mathrm{~cm}$ in that study was $3.38 \pm 1.15 \mathrm{Mg} \mathrm{C}_{\text {org }}$ ha $^{-1}$. Within the dataset used for the present study, the entire range of fertilization intensity was represented and the application of $\mathrm{C}_{\text {org }}$ allocation as a ratio of $\mathrm{NPP}_{\text {above }}$ to $\mathrm{NPP}_{\text {below }}$ would have caused large errors. Thus, we made use of our data published in Poeplau et al. (2018) and established a fixed and yield-independent value to estimate $\mathrm{NPP}_{\text {below }}$ as it appeared advisable according to latest publications. Based on the root- $\mathrm{C}_{\text {org }}$ stock of $3.38 \mathrm{Mg}$ $\mathrm{C}_{\text {org }}$ ha $^{-1}$ found by Poeplau et al. (2018), we assumed an average annual root turnover of $50 \%$ (Gill and Jackson 2000) and an additional $31 \%$ of annual root$\mathrm{C}_{\text {org }}$ produced being allocated belowground as rhizodeposition (Pausch and Kuzyakov 2018). The 
grassland's $\mathrm{NPP}_{\text {below }}$ was thus fixed to $2.2 \mathrm{Mg} \mathrm{C}_{\text {org }}$ $\mathrm{ha}^{-1} \mathrm{yr}^{-1}$, assuming that the assessment of root biomass to a depth of $100 \mathrm{~cm}$ approximately captured the total root biomass.

Calculation of annual carbon export from arable land and grassland

For arable sites, total annual $\mathrm{C}_{\text {org }}$ export $\left(\mathrm{Mg} \mathrm{C}_{\text {org }}\right.$ ha $^{-1}$ $\mathrm{yr}^{-1}$ ) occurs via the main product harvested, harvest residues when exported as side products, and cover crops when harvested for fodder or energy use. If a record indicated that a main product was not harvested and all biomass was tilled into the soil, as done for fallow (grass unharvested) or after extreme weather events, $\mathrm{C}_{\text {org }}$ export was set to zero. Information on whether harvest residues and/or cover crops were exported from the field was retrieved from the farmer questionnaire. If the use of a cover crop was not recorded, it was assumed here that its biomass was not exported, since this is estimated to be applied in $>80 \%$ of cases.

Total annual $\mathrm{C}_{\text {org }}$ export from arable sites $\left(\mathrm{A}-\mathrm{EX}_{\text {tot }}\right.$; $\mathrm{Mg} \mathrm{C}_{\text {org }} \mathrm{ha}^{-1} \mathrm{yr}^{-1}$ ) was calculated as the sum of $\mathrm{C}_{\mathrm{org}}$ export via main product, harvest residues and cover crops (CC-) harvested (Eq. 9). For export via main product and harvest residues, $\mathrm{C}_{\text {org }}$ allocation factors were applied to $\mathrm{NPP}_{\text {tot }}$ of the arable site (Eqs. 10, 11). For cover crops which were exported from the site it was suggested that export accounts for $75 \%$ of the biomass only (Bolinder et al. 2007) (Eq. 12).

$$
\begin{aligned}
& A-E X_{\text {tot }}=A-E X_{M P}+A-E X_{H R}+C C-E X \\
& A-E X_{M P}=A-N P P_{t o t} * C A_{M P} \\
& A-E X_{H R}=A-N P P_{t o t} * C A_{H R} \\
& C C-E X=C C-N P P_{\text {above }} * 0.75
\end{aligned}
$$

where $\mathrm{A}-\mathrm{EX}_{\mathrm{MP}}$ is the $\mathrm{C}_{\text {org }}$ export via the arable main crop $\left(\mathrm{Mg} \mathrm{C}_{\mathrm{org}} \mathrm{ha}^{-1} \mathrm{yr}^{-1}\right), \mathrm{A}-\mathrm{EX}_{\mathrm{HR}}$ is the $\mathrm{C}_{\text {org }}$ export of the harvest residues as side products $\left(\mathrm{Mg} \mathrm{C}_{\text {org }}\right.$ ha $^{-1}$ $\mathrm{yr}^{-1}$ ), CC-EX is the $\mathrm{C}_{\text {org }}$ export via the cover crop harvested $\left(\mathrm{Mg} \mathrm{C}_{\text {org }} \mathrm{ha}^{-1} \mathrm{yr}^{-1}\right), \mathrm{A}-\mathrm{NPP}_{\text {tot }}$ is the NPP of the arable site $\left(\mathrm{Mg} \mathrm{C}_{\mathrm{org}} \mathrm{ha}^{-1} \mathrm{yr}^{-1}\right), \mathrm{CA}_{\mathrm{MP}}$ is the $\mathrm{C}_{\text {org }}$ allocation factor of the main product, $\mathrm{CA}_{\mathrm{HR}}$ is the $\mathrm{C}_{\text {org }}$ allocation factor of the harvest residue, $\mathrm{CC}$ -
$\mathrm{NPP}_{\text {above }}$ is the $\mathrm{NPP}_{\text {above }}$ of the cover crop $\left(\mathrm{Mg} \mathrm{C}_{\text {org }}\right.$ $\mathrm{ha}^{-1} \mathrm{yr}^{-1}$ ), and 0.75 is the factor for the part of CCbiomass exported.

For grassland sites, the total annual $\mathrm{C}_{\text {org }}$ export (G$\mathrm{EX}_{\text {tot }} ; \mathrm{Mg} \mathrm{C}_{\text {org }} \mathrm{ha}^{-1} \mathrm{yr}^{-1}$ ) occurs via the yield as the main product on meadows and mown pastures, and via biomass uptake as the main product on pastures and mown pastures. It was calculated as:

$G-E X_{\text {tot }}=\left(G-M P+G-M P_{u p}\right) * 0.45$

where G-MP is the dry matter yield of the main product of the grassland site $\left(\mathrm{Mg} \mathrm{ha}^{-1} \mathrm{yr}^{-1}\right), \mathrm{G}-\mathrm{MP}_{\mathrm{up}}$ is the biomass taken up by animals $\left(\mathrm{Mg} \mathrm{ha}^{-1} \mathrm{yr}^{-1}\right)$, 0.45 is the $\mathrm{C}_{\text {org }}$ content $\left(\mathrm{Mg} \mathrm{Mg}^{-1}\right.$ dry matter $\left.{ }^{-1}\right)$ of aboveground biomass (Bolinder et al. 2007).

Calculation of plant-derived annual carbon inputs on arable and grassland soils

On arable sites, the plant-derived annual $\mathrm{C}_{\text {org }}$ input to soil ( $\mathrm{Mg} \mathrm{C}_{\mathrm{org}} \mathrm{ha}^{-1} \mathrm{yr}^{-1}$ ) occurs via harvest residues if left in the field (as recorded in the questionnaire), stubbles which always remain in the field, roots, rhizodeposition, and cover crops. For this study, it was not differentiated in which soil depth the $\mathrm{C}_{\text {org }}$ was incorporated by tillage since the focus was rather on the amount of $\mathrm{C}_{\text {org }}$ left on the site. If a cover crop was recorded as being exported, it was assumed that $25 \%$ of its $\mathrm{NPP}_{\text {above }}$ was left in the field as stubbles (Bolinder et al. 2007).

The total $\mathrm{C}_{\text {org }}$ input to arable soils (A-IN $\mathrm{Ito}_{\text {to }} ; \mathrm{Mg} \mathrm{C}_{\text {org }}$ $\mathrm{ha}^{-1} \mathrm{yr}^{-1}$ ) was calculated as (although sources of plant-derived $\mathrm{C}_{\text {org }}$ input are shown separately):

$A-I N_{t o t}=\left(A-N P P_{t o t}-A-E X_{t o t}\right)$

where A-NPP ${ }_{\text {tot }}$ is the $\mathrm{NPP}_{\text {tot }}$ of the arable site $(\mathrm{Mg}$ $\mathrm{C}_{\text {org }} \mathrm{ha}^{-1} \mathrm{yr}^{-1}$ ) and $\mathrm{A}-\mathrm{EX}_{\text {tot }}$ is the $\mathrm{C}_{\text {org }}$ export from the site $\left(\mathrm{Mg} \mathrm{C}_{\text {org }} \mathrm{ha}^{-1} \mathrm{yr}^{-1}\right)$.

On grassland sites, the plant-derived annual $\mathrm{C}_{\text {org }}$ input to soil occurs via mulch, decaying aboveground, and belowground residues of the main product. Decaying aboveground residues were suggested to comprise $50 \%$ of the biomass produced that was not harvested or grazed (Poeplau 2016). The $\mathrm{C}_{\text {org }}$ input from decaying belowground residues (roots and rhizodeposition) was equal to $\mathrm{NPP}_{\text {below }}\left(2.2 \mathrm{Mg} \mathrm{C_{ \text {org } }}\right.$ $\mathrm{ha}^{-1} \mathrm{yr}^{-1}$ ). This was based on the notion that in a 
mature permanent grassland, annual root biomass growth and turnover are in a steady state.

The annual $\mathrm{C}_{\text {org }}$ input to grassland soils $\left(\mathrm{G}_{-} \mathrm{IN}_{\text {tot }}\right.$; $\mathrm{Mg} \mathrm{C}_{\text {org }} \mathrm{ha}^{-1} \mathrm{yr}^{-1}$ ) was calculated as:

$$
\begin{aligned}
& G-I N_{t o t}=[M U * 0.45]+\left[\left(G-N P P_{\text {above }}\right.\right. \\
& \left.\left.-G-E X_{t o t}-(M U * 0.45)\right) * 0.5\right]+2.22
\end{aligned}
$$

where MU is the dry matter biomass mulched ( $\left.\mathrm{Mg} \mathrm{ha}^{-1} \mathrm{yr}^{-1}\right), 0.45$ is the $\mathrm{C}_{\text {org }}$ content $\left(\mathrm{Mg} \mathrm{Mg}^{-1}\right.$ dry matter ${ }^{-1}$ ) of aboveground biomass (Bolinder et al. 2007), G-NPP above $_{\text {is the }} \mathrm{NPP}_{\text {above }}$ of the grassland site ( $\mathrm{Mg} \mathrm{C}_{\text {org }} \mathrm{ha}^{-1} \mathrm{yr}^{-1}$ ), G-EX $\mathrm{X}_{\text {tot }}$ is the $\mathrm{C}_{\text {org }}$ export from the grassland site $\left(\mathrm{Mg} \mathrm{C}_{\mathrm{org}} \mathrm{ha}^{-1} \mathrm{yr}^{-1}\right), 0.5$ is the factor respecting the $50 \%$ biomass decaying (see above), and $2.22 \mathrm{Mg} \mathrm{C}$ org ha $\mathrm{hr}^{-1}$ is the $\mathrm{C}_{\text {org }}$ input from decaying belowground residues (see above).

Calculation of annual carbon inputs via organic fertilizers and grazing animal excreta

For arable and grassland sites, the annual $\mathrm{C}_{\text {org }}$ input via organic fertilizers ( FER $_{\text {org }}$-IN; $\mathrm{Mg} \mathrm{C}_{\text {org }}$ ha $^{-1} \mathrm{yr}^{-1}$ ) was calculated according to information recorded in the questionnaire:

$$
F E R_{\text {org }}-I N=F E R_{\text {org }} * D M_{F E R} * C_{F E R}
$$

where $\mathrm{FER}_{\text {org }}$ is the fresh matter amount of the specific organic fertilizer applied $\left(\mathrm{Mg} \mathrm{ha}^{-1} \mathrm{yr}^{-1}\right)$ where a density of $1 \mathrm{Mg} \mathrm{m}^{-3}$ was assumed for all liquid organic fertilizers, $\mathrm{DM}_{\mathrm{FER}}$ is its dry matter content $\left(\mathrm{Mg} \mathrm{Mg}^{-1}\right), \mathrm{CF}_{\mathrm{FER}}$ is its $\mathrm{C}_{\text {org }}$ content $\left(\mathrm{Mg} \mathrm{Mg}^{-1}\right.$ dry matter ${ }^{-1}$ ) which both were obtained in a broad literature search (Table S5).

To estimate the annual $\mathrm{C}_{\text {org }}$ input to soil from animal excreta on pastures and mown pastures, the number and species of animals on the site were multiplied by excretion rates expected for species, as estimated by Rösemann et al. (2017) (Table S3). When the respective information was not recorded, missing data were replaced by dividing the number and species of animals grazing on the entire farm (as given in all cases) by the amount of grassland grazed on the farm.

The annual $\mathrm{C}_{\text {org }}$ input to the soil via grazing animals excreta $\left(\mathrm{FER}_{\mathrm{ani}}\right.$-IN; $\mathrm{Mg} \mathrm{C}$ org $\left.\mathrm{ha}^{-1} \mathrm{yr}^{-1}\right)$ was calculated as:

$\mathrm{FER}_{\mathrm{ani}}-\mathrm{IN}=\mathrm{FER}_{\mathrm{ani}} * \mathrm{C}_{\mathrm{FER}}$ where $\mathrm{FER}_{\mathrm{an}}$ is the dry matter amount of grazing animals excreta $\left(\mathrm{Mg} \mathrm{ha}^{-1} \mathrm{yr}^{-1}\right)$ and $\mathrm{C}_{\mathrm{FER}}$ is its $\mathrm{C}_{\text {org }}$ content $\left(\mathrm{Mg} \mathrm{Mg}^{-1}\right.$ dry matter ${ }^{-1}$; Table S5).

\section{Results}

Net primary production on and export of organic carbon from arable and grassland sites

The majority of crops cultivated on German arable soils between 2001 and 2015 were winter wheat, silage maize, oil seed rape, and winter barley which were cultivated in $65 \%$ of all arable site * years evaluated (Table 2). Carbon fixation as mean annual NPP tot by main crops and cover crops on arable sites was $6.9 \pm 2.3 \mathrm{Mg} \mathrm{C}_{\text {org }} \mathrm{ha}^{-1} \mathrm{yr}^{-1}$ (Fig. 1). The values of the main crops' $\mathrm{NPP}_{\text {above }}$ and $\mathrm{NPP}_{\text {below }}$ were specific for each crop type (Table 2). On average, $74.9 \pm 9.7 \%$ of $\mathrm{NPP}_{\text {tot }}$ on arable sites was in aboveground biomass while $25.1 \pm 9.7 \%$ was allocated to roots and rhizodeposition of main crops and cover crops. Cover crops contributed $3 \pm 10 \%$ of $\mathrm{NPP}_{\text {tot }}$ and were grown in $11 \%$ of all arable site * years evaluated. They were most often cultivated after cereals (winter barley, summer barley, winter triticale, winter rye, winter wheat) or were associated with silage maize cultivation. In this group of main crops, cover crops were grown on an average of $16 \%$ of all site * years evaluated (Table S6). Mean annual total $\mathrm{C}_{\text {org }}$ export from arable sites via harvest of main product, harvest residues exported as side product and cover crops was $3.7 \pm 1.8 \mathrm{Mg} \mathrm{C}_{\text {org }} \mathrm{ha}^{-1} \mathrm{yr}^{-1}$ (Table 2, Fig. 1), of which $0.4 \pm 0.8 \mathrm{Mg} \mathrm{C}$ org ha $\mathrm{hr}^{-1}$ was in side products, such as straw. Harvest residues were exported as side product in $43 \%$ of all arable site * years evaluated (Table S6).

On grasslands, mean annual $\mathrm{NPP}_{\text {tot }}$ was $5.9 \pm 2.9 \mathrm{Mg} \mathrm{C}_{\text {org }} \mathrm{ha}^{-1} \mathrm{yr}^{-1}$, which was on average lower than on arable sites (Fig. 1). However, $\mathrm{NPP}_{\text {below }}$ of grassland sites, which was estimated with a fixed value of $2.2 \mathrm{Mg} \mathrm{C}_{\mathrm{org}} \mathrm{ha}^{-1} \mathrm{yr}^{-1}$, contributed to a larger share (average $43 \pm 14 \%$ of $\mathrm{NPP}_{\text {tot }}$ ) to $\mathrm{NPP}_{\text {tot }}$ than on arable sites. Mean annual $\mathrm{C}_{\text {org }}$ export was $3.0 \pm 2.3 \mathrm{Mg} \mathrm{C}_{\mathrm{org}} \mathrm{ha}^{-1} \mathrm{yr}^{-1}$ (Fig. 1) of which $1.9 \pm 1.4 \mathrm{Mg} \mathrm{C}$ org $\mathrm{ha}^{-1} \mathrm{yr}^{-1}$ was via cutting of meadows and mown pastures and $1.1 \pm 2.2 \mathrm{Mg} \mathrm{C}_{\text {org }}$ $\mathrm{ha}^{-1} \mathrm{yr}^{-1}$ was taken up by grazing animals. Meadows 
Table 2 Share of main crops cultivated of annual fluxes of organic carbon $\left(\mathrm{C}_{\mathrm{org}} ; \mathrm{Mg} \mathrm{C}_{\text {org }} \mathrm{ha}^{-1} \mathrm{yr}^{-1}\right)$ as net primary production (NPP) for main crops (total and belowground) and cover crops, $\mathrm{C}_{\text {org }}$ export via main product and via harvest residues exported as side products, and plant-derived $\mathrm{C}_{\text {org }}$ input; values are the mean and standard deviation (SD) calculated from the multiplication of sites and years (site * years) recorded within the German Agricultural Soil Inventory and are given for crops with a minimum share of $1 \%$ across all records

\begin{tabular}{|c|c|c|c|c|c|c|c|c|c|c|c|c|c|c|c|}
\hline \multirow[t]{3}{*}{ Crop } & \multirow{3}{*}{$\begin{array}{l}\text { Share of } \\
\text { site * years } \\
(\%)\end{array}$} & \multicolumn{6}{|l|}{ NPP } & \multicolumn{4}{|c|}{$\mathrm{C}_{\text {org }}$ export } & \multicolumn{4}{|c|}{$\mathrm{C}_{\text {org }}$ input } \\
\hline & & \multicolumn{2}{|c|}{$\begin{array}{l}\text { Main crop } \\
\left(\mathrm{NPP}_{\text {total }}\right)\end{array}$} & \multicolumn{2}{|c|}{$\begin{array}{l}\text { Main crop } \\
\left(\mathrm{NPP}_{\text {belowground }}\right)\end{array}$} & \multicolumn{2}{|c|}{ Cover crop } & \multicolumn{2}{|c|}{$\begin{array}{l}\text { Main } \\
\text { product }\end{array}$} & \multicolumn{2}{|c|}{$\begin{array}{l}\text { Side } \\
\text { product }\end{array}$} & \multicolumn{2}{|c|}{ Fertilizer } & \multicolumn{2}{|l|}{ Total } \\
\hline & & Mean & SD & Mean & SD & Mean & SD & Mean & SD & Mean & SD & Mean & SD & Mean & SD \\
\hline \multicolumn{16}{|l|}{ Arable } \\
\hline Winter wheat & 26.4 & 7.2 & 1.4 & 1.8 & 0.4 & 0.3 & 0.9 & 3 & 0.6 & 0.8 & 1.0 & 0.3 & 0.7 & 4 & 1.6 \\
\hline Silage maize & 14.1 & 7.7 & 1.7 & 1.5 & 0.3 & 0.3 & 1 & 5.9 & 1.3 & 0 & 0 & 1.2 & 1 & 3.2 & 1.4 \\
\hline Oil seed rape & 12.2 & 6.8 & 1.5 & 2.0 & 0.4 & 0.1 & 0.4 & 2.2 & 0.5 & 0.1 & 0.3 & 0.3 & 0.6 & 4.9 & 1.3 \\
\hline Winter barley & 11.9 & 6.1 & 1.3 & 1.4 & 0.3 & 0.6 & 1.1 & 2.7 & 0.6 & 0.8 & 0.9 & 0.4 & 0.8 & 3.5 & 1.6 \\
\hline Winter rye & 5.9 & 4.7 & 1.8 & 1.1 & 0.4 & 0.4 & 1 & 1.9 & 0.7 & 0.8 & 0.8 & 0.3 & 0.7 & 2.7 & 1.6 \\
\hline Summer barley & 4 & 4.8 & 1.1 & 1.3 & 0.3 & 0.5 & 1.1 & 2 & 0.5 & 0.5 & 0.6 & 0.3 & 0.6 & 3 & 1.4 \\
\hline Sugar beet & 3.9 & 8.7 & 1.6 & 0.4 & 0.1 & 0.2 & 0.7 & 6.9 & 1.3 & 0 & 0.1 & 0.6 & 1.4 & 2.6 & 1.6 \\
\hline Grain maize & 3.7 & 10.4 & 2.7 & 2.7 & 0.7 & 0.1 & 0.4 & 4.1 & 1.1 & 0.1 & 0.7 & 0.5 & 0.7 & 6.8 & 1.8 \\
\hline Winter triticale & 3.3 & 5.5 & 1.5 & 1.1 & 0.3 & 0.5 & 1.1 & 2.3 & 0.6 & 1 & 0.9 & 0.4 & 0.6 & 3.2 & 1.7 \\
\hline Fallow $^{1}$ & 3 & 3.6 & 0.4 & 2.1 & 0.4 & 0 & 0.2 & 1.3 & 0 & 0 & 0 & 0 & 0 & 3.7 & 0.4 \\
\hline Potato & 2.2 & 5.4 & 1.3 & 0.2 & 0.1 & 0.2 & 0.8 & 4.3 & 1 & 0 & 0 & 0.4 & 0.7 & 1.7 & 1.1 \\
\hline $\begin{array}{l}\text { Grass without } \\
\text { legumes } \\
\text { (whole plant) }\end{array}$ & 1.4 & 5.7 & 2.2 & 2.5 & 0.6 & 0.1 & 0.5 & 3 & 1.5 & 0 & 0 & 0.7 & 0.8 & 3.4 & 1.3 \\
\hline Summer oat & 1.4 & 5.8 & 1.8 & 2.0 & 0.6 & 0.2 & 0.8 & 1.8 & 0.6 & 0.9 & 0.9 & 0.5 & 0.8 & 3.8 & 1.6 \\
\hline Grain legumes & 1.1 & 3.5 & 1.8 & 0.7 & 0.4 & 0.3 & 0.8 & 1.3 & 0.7 & 0 & 0.1 & 0.2 & 0.7 & 2.6 & 1.6 \\
\hline $\begin{array}{l}\text { Grass with } \\
\text { legumes } \\
\text { (whole plant) }\end{array}$ & 1.1 & 5.3 & 2.1 & 2.6 & 1.3 & 0.1 & 0.4 & 2.3 & 1.1 & 0 & 0 & 0.7 & 0.9 & 3.7 & 1.7 \\
\hline Other crops & 4.3 & 4.9 & 1.8 & 1.8 & 0.7 & 0.3 & 0.7 & 2.3 & 0.9 & 0.2 & 0.3 & 0.4 & 0.6 & 3.2 & 1.3 \\
\hline Average & & 6.6 & 2.1 & 1.6 & 0.4 & 0.3 & 0.9 & 3.2 & 1.7 & 1.1 & 1.1 & 0.5 & 0.8 & 3.7 & 1.8 \\
\hline \multicolumn{16}{|l|}{ Grassland } \\
\hline Meadow & 44.5 & 5.6 & 1.4 & & & - & - & 2.8 & 1.2 & 0.0 & 0.0 & 0.7 & 0.9 & 3.5 & 1.0 \\
\hline Mown pasture & 40.3 & 6.4 & 3.3 & & & - & - & 3.4 & 2.7 & 0.0 & 0.0 & 1.0 & 1.0 & 4.0 & 1.4 \\
\hline Pasture & 15.2 & 5.6 & 4.3 & & & - & - & 2.7 & 3.5 & 0.0 & 0.0 & 0.7 & 0.8 & 3.5 & 1.5 \\
\hline Average & & 5.9 & 2.9 & & & - & - & 3.0 & 2.4 & 0.0 & 0.0 & 0.8 & 1.0 & 3.7 & 1.3 \\
\hline
\end{tabular}

${ }^{1}$ 'Fallow' is not to be interpreted as bare fallow but as years of non-cultivation during which soil is covered by (volunteer) grass which is not harvested

mown up to six times per year were the prevailing management type on grasslands (44\% of all grassland site * years evaluated), while pastures used only for grazing represented $15 \%$ of all grassland site * years evaluated (Table 2).
Carbon inputs to agricultural soils

Total mean annual $\mathrm{C}_{\text {org }}$ input to soils did not differ between arable $\left(3.7 \pm 1.8 \mathrm{Mg} \mathrm{C}_{\text {org }} \mathrm{ha}^{-1} \mathrm{yr}^{-1}\right)$ and grassland sites $\left(3.7 \pm 1.3 \mathrm{Mg} \quad \mathrm{C}_{\mathrm{org}} \mathrm{ha}^{-1} \mathrm{yr}^{-1}\right)$ (Fig. 2). Across all arable crops, $\mathrm{NPP}_{\text {tot }}\left(\mathrm{R}^{2}=0.47\right)$, rather than $\mathrm{C}_{\text {org }}$ input via organic fertilizer $\left(\mathrm{R}^{2}=0.11\right)$ 

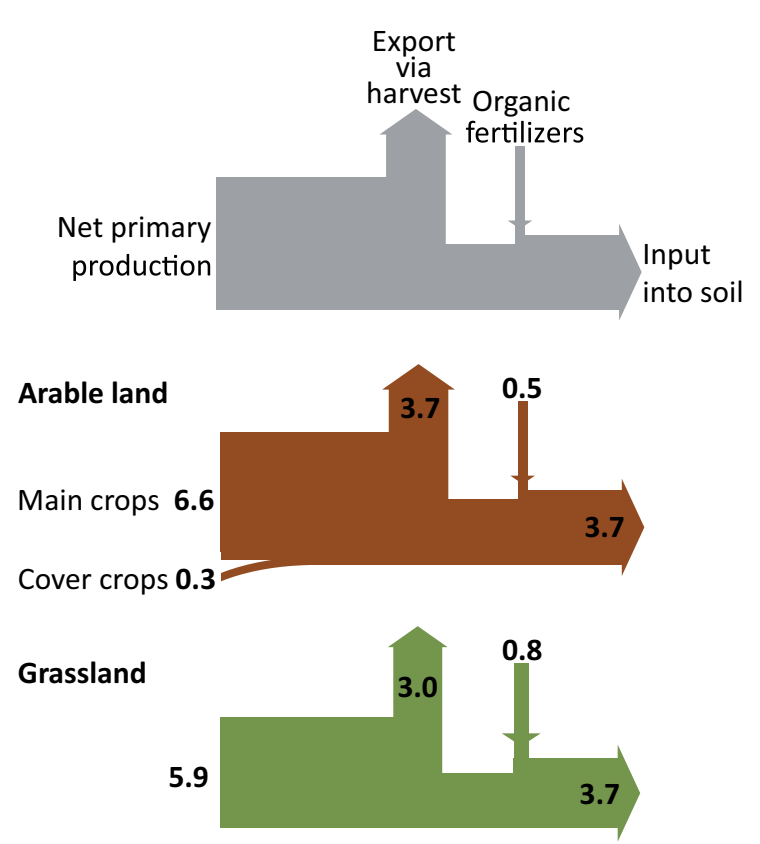

Fig. 1 Mean fluxes of organic carbon $\left(\mathrm{C}_{\mathrm{org}}, \mathrm{Mg} \mathrm{C}_{\mathrm{org}} \mathrm{ha}^{-1} \mathrm{yr}^{-1}\right)$ on agricultural soils in Germany calculated for the multiplication of sites and years recorded within the German Agricultural Soil Inventory (arable: $n=19,987$; grassland: $n=7417$ ); for grassland soils, harvest includes biomass uptake of animals and fertilizers include excreta of animals

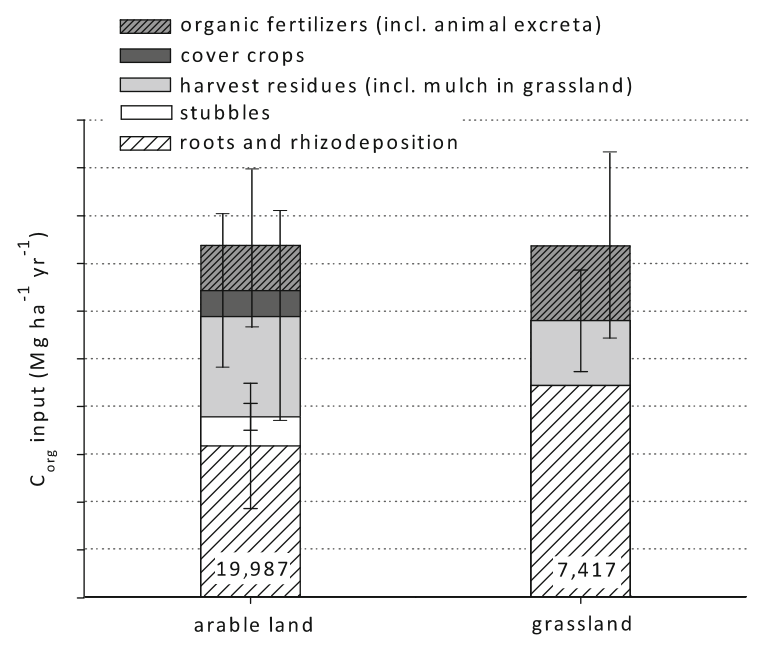

Fig. 2 Sources of mean annual input of organic carbon $\left(\mathrm{C}_{\mathrm{org}}\right)$ to arable and grassland soils calculated for the multiplication of sites and years recorded within the German Agricultural Soil Inventory; mean value and standard deviation. $\mathrm{C}_{\text {org }}$ input via roots and rhizodeposition in grassland estimated as a fixed value (see text for details) of $2.2 \mathrm{Mg} \mathrm{ha}^{-1} \mathrm{yr}^{-1}$ and therefore shown without standard deviation or $\mathrm{C}_{\text {org }}$ export $\left(\mathrm{R}^{2}=0.03\right)$, was the main driver of total $\mathrm{C}_{\text {org }}$ input to the soil (Figure S1).

The largest proportion $(83 \pm 23 \% ; 3.0 \pm 1.5 \mathrm{Mg}$ $\mathrm{C}_{\text {org }} \mathrm{ha}^{-1} \mathrm{yr}^{-1}$; Fig. 2) of total mean annual $\mathrm{C}_{\text {org }}$ input to arable soils was via above- and belowground plant material of the main crop with $1.6 \pm 0.7 \mathrm{Mg} \mathrm{C}_{\text {org }}$ $\mathrm{ha}^{-1} \mathrm{yr}^{-1}$ from roots and rhizodeposition, $0.3 \pm 0.1 \mathrm{Mg} \mathrm{C}_{\text {org }} \mathrm{ha}^{-1} \mathrm{yr}^{-1}$ from stubbles, and $1.1 \pm 1.1 \mathrm{Mg} \mathrm{C}_{\text {org }} \mathrm{ha}^{-1} \mathrm{yr}^{-1}$ from harvest residues left in the field. Cover crops accounted for $5 \pm 15 \%$ of the total mean annual $\mathrm{C}_{\text {org }}$ input to soil with on average $0.3 \pm 0.8 \mathrm{Mg} \mathrm{C}_{\text {org }} \mathrm{ha}^{-1} \mathrm{yr}^{-1}$. Organic fertilizers accounted for $12 \pm 18 \%$ of the total mean annual $\mathrm{C}_{\text {org }}$ input to arable soils with $0.5 \pm 0.8 \mathrm{Mg} \mathrm{C}_{\text {org ha }}{ }^{-1}$ $\mathrm{yr}^{-1}$. They were applied on $71 \%$ of all arable sites and in $43 \%$ of all site * years evaluated and derived mainly (94\%) from animals (including biogas digestates). Among arable crops, the highest average $\mathrm{C}_{\text {org }}$ input was found for grain maize cultivation, due to very high average $\mathrm{NPP}_{\text {tot }}\left(10.4 \pm 2.7 \mathrm{Mg} \mathrm{C}_{\text {org }} \mathrm{ha}^{-1} \mathrm{yr}^{-1}\right)$ and a low portion of $\mathrm{C}_{\text {org }}$ export via harvest (40\%, Table 2). The lowest $\mathrm{C}_{\text {org }}$ input (lower quantile $=1 \%$ ) was found for potato cultivation $\left(1.1 \pm 0.3 \mathrm{Mg} \mathrm{C}_{\mathrm{org}} \mathrm{ha}^{-1}\right.$ $\mathrm{yr}^{-1}$ ) mainly due to its high harvest index of 0.83 . Sites with very high $\mathrm{C}_{\text {org }}$ input $\left(>7.6 \mathrm{Mg} \mathrm{C}_{\mathrm{org}} \mathrm{ha}^{-1} \mathrm{yr}^{-1}\right.$ ) (upper quantile $=99 \%$ ) had a regular cover crop cultivation and/or were fertilized with compost and/or manure.

As found for arable soils, the largest proportion of total mean annual $\mathrm{C}_{\text {org }}$ input to grassland soils was again via plant biomass $(83 \pm 15 \%$ or $2.9 \pm 0.5 \mathrm{Mg}$ $\mathrm{C}_{\text {org }} \mathrm{ha}^{-1} \mathrm{yr}^{-1}$ ) (Fig. 2) of which the fixed value of $2.2 \mathrm{Mg} \mathrm{C}_{\mathrm{org}} \mathrm{ha}^{-1} \mathrm{yr}^{-1}$ deriving from roots and rhizodeposition had the largest share. The remaining $0.7 \pm 0.5 \mathrm{Mg} \mathrm{C}_{\text {org }} \mathrm{ha}^{-1} \mathrm{yr}^{-1}$ derived from aboveground residues and mulching. Mulching of grassland was recorded for $2 \%$ of all grassland site * years evaluated. Organic fertilizers accounted for $17 \pm 15 \%$ of total mean annual $\mathrm{C}_{\text {org }}$ input to grassland soils with $0.8 \pm 1.0 \mathrm{Mg} \mathrm{C}_{\text {org }} \mathrm{ha}^{-1} \mathrm{yr}^{-1}$. They were distributed on $81 \%$ of grassland sites and in $45 \%$ of all grassland site * years evaluated. This high number reflects the fact that excreta from grazing animals were considered here as organic fertilizers. Meadows received organic fertilizers in $51 \%$ of all grassland site * years evaluated. There were only two cases where organic fertilizers did not derive from animals (sewage sludge, potato processing sludge). Sites with low $\mathrm{C}_{\text {org }}$ input $\left(<2.3 \mathrm{Mg} \mathrm{C}_{\text {org }} \mathrm{ha}^{-1} \mathrm{yr}^{-1}\right.$ ) (lower 


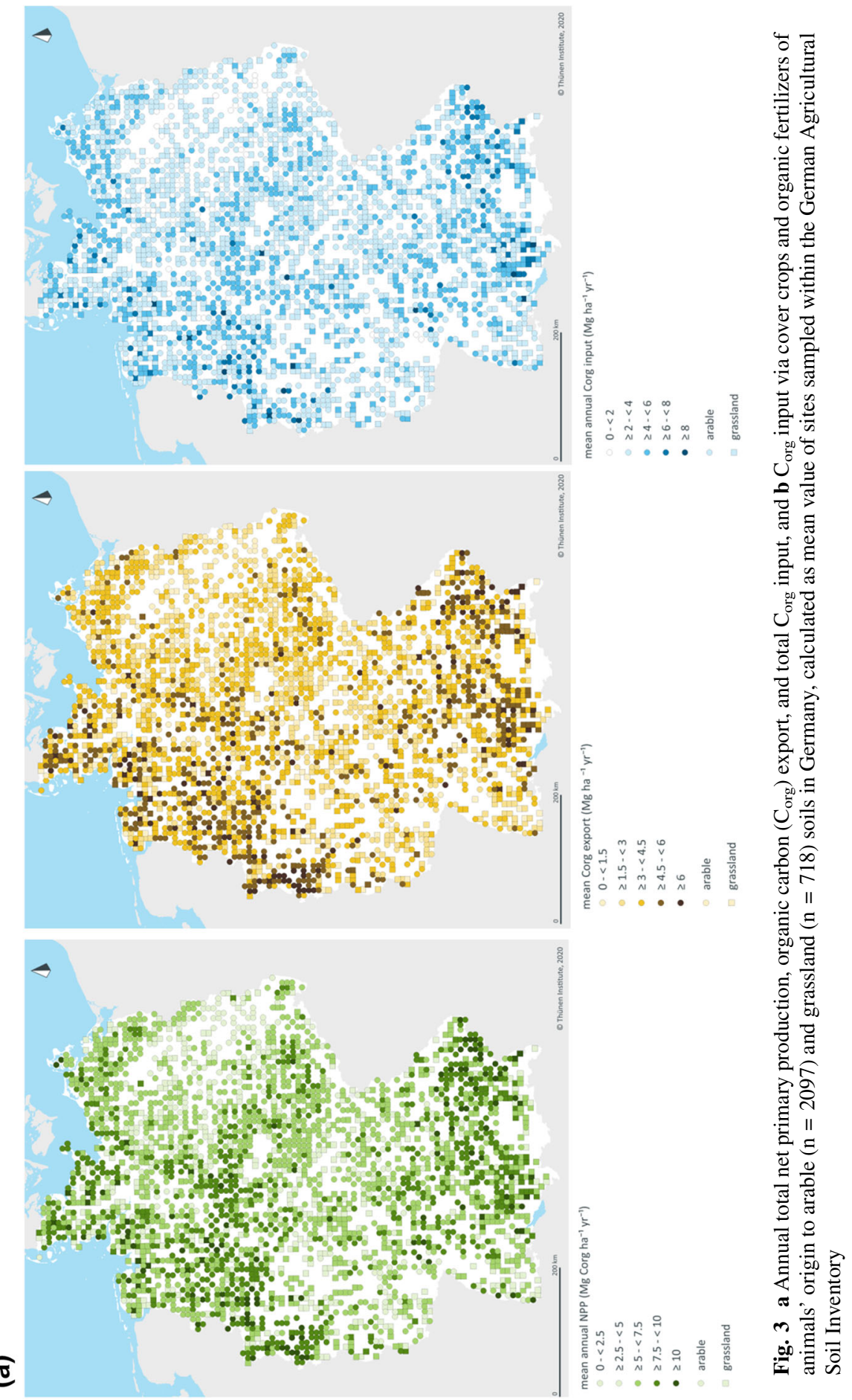




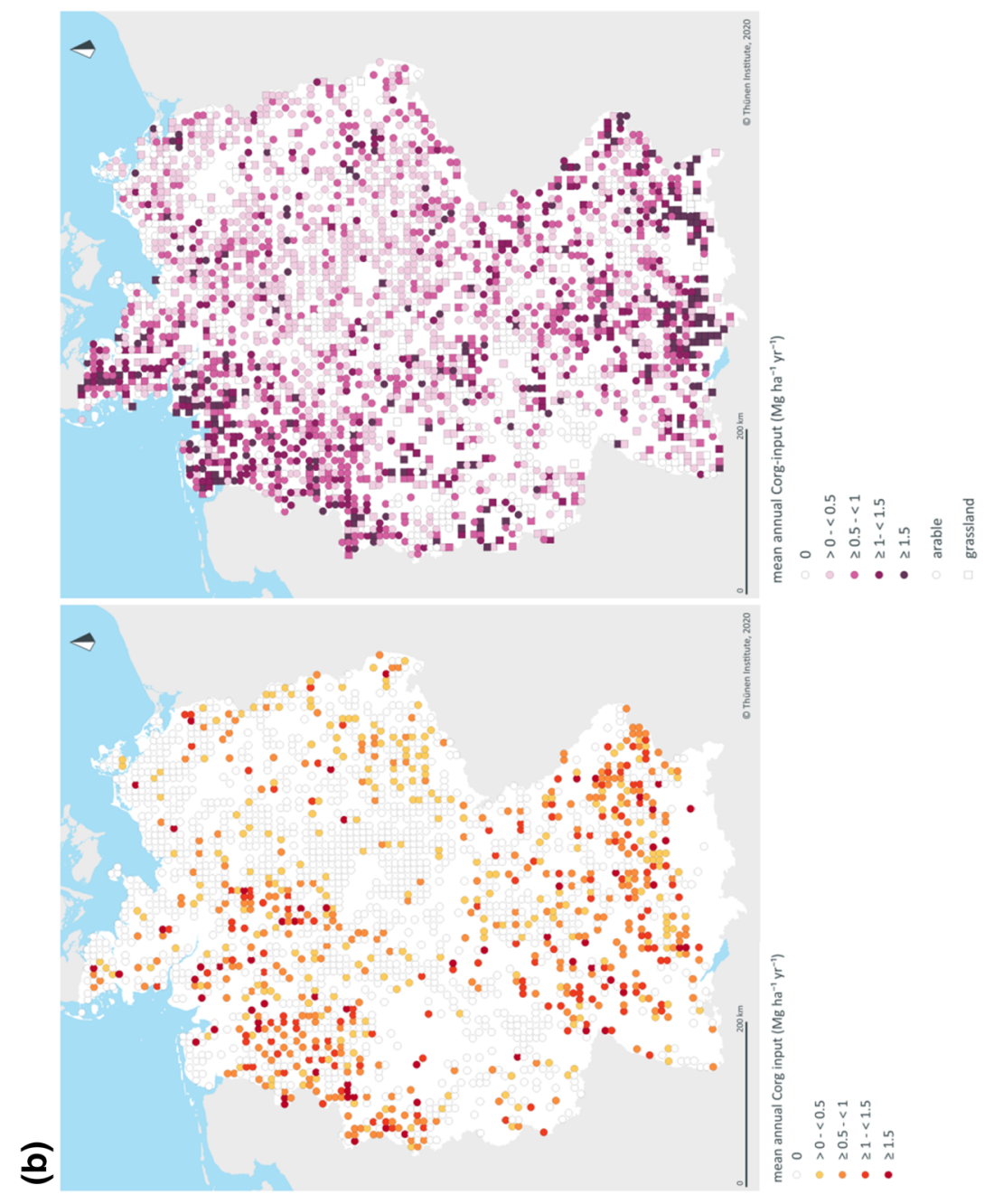

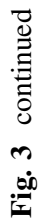




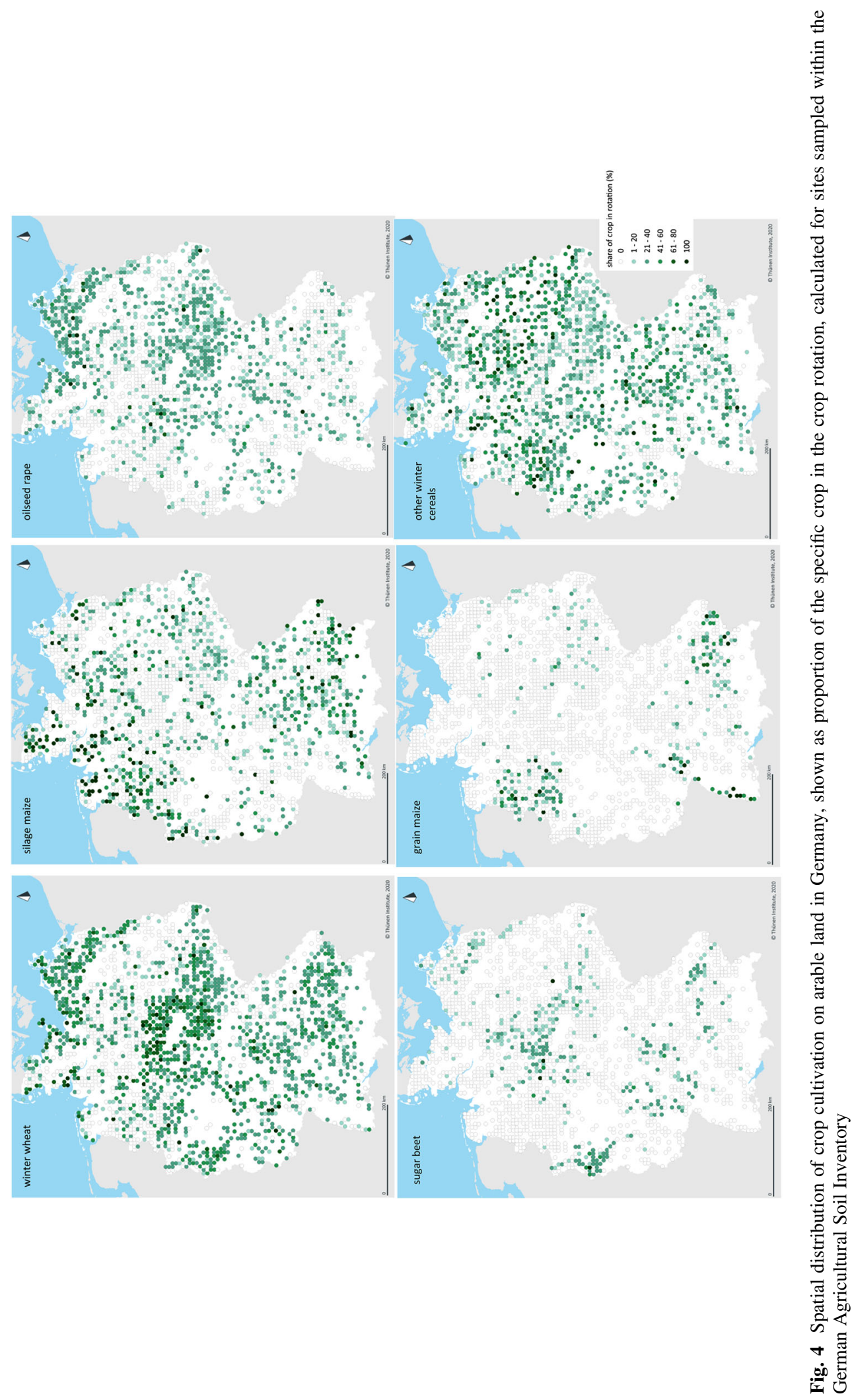


quantile $=1 \%$ ) were characterized by low yield level and no organic fertilization. Sites with a high $\mathrm{C}_{\text {org }}$ input (>7.6 Mg C $\mathrm{C}_{\text {org }} \mathrm{ha}^{-1} \mathrm{yr}^{-1}$ ) (upper quantile $=99 \%$ ) were pastures with high animal grazing density or received a large amount of organic fertilizer and/or had a high yield level expressed as high number of cuts per year.

Spatial distribution of net primary production and inputs and exports of organic carbon

The highest $\mathrm{NPP}_{\text {tot }}$ and $\mathrm{C}_{\text {org }}$ export values were obtained for north-west and south-east Germany (Fig. 3a). Figure 4 shows the spatial distribution of the crops most often cultivated, i.e., winter wheat, silage maize, oilseed rape, sugar beet, grain maize, and other winter cereals. Each of the crops is preferentially grown in certain areas, which partly explains the spatial pattern of $\mathrm{NPP}_{\text {tot }}$ found in this study. In particular, the distribution of silage maize cultivation explains the high values of $\mathrm{NPP}_{\text {tot }}$ and $\mathrm{C}_{\text {org }}$ export in north-west and south-east Germany. The $\mathrm{C}_{\text {org }}$ input from cover crops was also highest in these areas (Fig. 3b), most likely driven by high precipitation (mean annual precipitation of, e.g., $910 \mathrm{~mm}$ in Bavaria in contrast to the German average of $771 \mathrm{~mm}$; mean values of 1881-2019 of Deutscher Wetterdienst 2020) and the specific crop rotation (maize-dominated). North-west and south-east Germany are also areas of high livestock density, explaining the high amounts of $\mathrm{C}_{\text {org }}$ input via organic fertilizers (Fig. 3b). Regions with the most fertile soils, such as the young moraine soils of north-east Germany and the central German chernosem area, were dominated by the cultivation of winter wheat and oilseed rape. In these regions, the major source of $\mathrm{C}_{\mathrm{org}}$ input to soil was harvest residues left in the field. In the central German chernosem area in particular, but also in large parts of eastern Germany, cover crops did not play any role in the crop rotation. This can be explained by the lower annual precipitation, e.g., with an average of $566 \mathrm{~mm}$ and $600 \mathrm{~mm}$ in Brandenburg and Mecklenburg-Western Pomerania (mean values of 1881-2019 of Deutscher Wetterdienst 2020). Moreover, crop rotations in those areas are winter cropdominated.

Finally, $\mathrm{C}_{\mathrm{org}}$ input was more regionally variable and site-specific than $\mathrm{C}$ assimilation by plants, estimated here as $\mathrm{NPP}_{\text {tot. }}$. However, the pattern of
$\mathrm{NPP}_{\text {tot }}$ was still visible in the map showing the spatial distribution of $\mathrm{C}_{\text {org }}$ input (Fig. 3a), confirming $\mathrm{NPP}_{\text {tot }}$ as a strong driver for $\mathrm{C}_{\text {org }}$ input.

\section{Discussion}

More than half of carbon assimilated is exported from German agricultural soils

Based on our method, mean annual $\mathrm{NPP}_{\text {tot }}$ on arable sites in Germany was estimated $6.9 \mathrm{Mg} \mathrm{C}_{\text {org }}$ $\mathrm{ha}^{-1} \mathrm{yr}^{-1}$ and was slightly higher than on grasslands (5.9 $\mathrm{Mg} \mathrm{C}_{\text {org }} \mathrm{ha}^{-1} \mathrm{yr}^{-1}$ ) despite the fact that grasslands are characterized by permanent vegetation cover and, thus, potentially maximized C-assimilation. This is well in line with global estimates of $\mathrm{NPP}_{\text {tot. }}$. Using the earth surface model LPJ, Haberl et al. (2007) estimated mean annual global NPP tot $_{\text {of }}$ $6.1 \mathrm{Mg} \mathrm{C}_{\text {org }} \mathrm{ha}^{-1} \mathrm{yr}^{-1}$ on arable land and $4.9 \mathrm{Mg}$ $\mathrm{C}_{\text {org }} \mathrm{ha}^{-1} \mathrm{yr}^{-1}$ on grazing land. The higher values we obtained in the present study might be due to intensive management regime in German agriculture and to generally fertile and relatively young soils. Management, e.g. fertilization, and differences in pedoclimatic site properties are the most important drivers for the differences in $\mathrm{NPP}_{\text {tot }}$ between arable land and grassland. Grasslands in Germany are characterized by a range of management intensities, from unmanaged to intensively managed, whereas arable sites are mostly intensively managed and fertilized. Further, a large proportion of permanent grasslands in Germany are established in conditions that do not favor cultivation of arable crops, e.g., on wet soils in floodplains, shallow and stony soils, and colder mountainous regions.

On average, $53 \%$ of the $\mathrm{NPP}_{\text {tot }}$ on arable sites was found to be exported each year. Of this exported $\mathrm{C}_{\mathrm{org}}$ portion, $11 \%$ was in harvest residues which were exported as side products. This fact was strongly cropdependent: Aboveground biomass of crops dedicated for forage or energy production, e.g. silage maize, does not deliver any side products, while harvest residues of cash crops other than cereals, such as oilseed rape, sugar beet or potatoes, are completely left on the site (Table S6). Among all cereals, $40 \%$ of all arable site * years evaluated, which is equivalent to $42 \%$ of all cereal straw biomass (not shown), was recorded with an export of straw as side product. This value is somewhat larger than the $27-38 \%$ estimated 
in a review on biomass potentials in Germany by Brosowski et al. (2016). Of the $\mathrm{C}_{\text {org }}$ portion exported, only $15 \%$ ended up in organic fertilizers returned to arable soils as $\mathrm{C}_{\text {org }}$ input. This is comparable to other estimates for Europe showing $47 \%$ of $\mathrm{NPP}_{\text {tot }}$ being exported via harvest of arable crops and $10 \%$ of $\mathrm{NPP}_{\text {tot }}$ being returned as organic fertilizers (Schulze et al. 2009). German grasslands are characterized by high productivity and a relatively high portion of $\mathrm{NPP}_{\text {tot }}$ being exported (51\%). At European scale, it was estimated that only $37 \%$ of grassland $\mathrm{NPP}_{\text {tot }}$ is exported via harvest (Schulze et al. 2009), which underlines the high intensity of German grassland usage. Of the $\mathrm{C}_{\text {org }}$ portion exported, $27 \%$ ended up in organic fertilizers (including animal excreta) returned to grassland soils as a $\mathrm{C}_{\text {org }}$ input. On a global scale, Haberl et al. (2007) estimated that the proportion of $\mathrm{NPP}_{\text {tot }}$ harvested was $83 \%$ on arable land and $19 \%$ on grazing land. This indicates that $\mathrm{C}_{\text {org }}$ export via harvest is subject to uncertainties and strongly region-specific.

Total organic carbon inputs into soils do not differ between land use systems

The $\mathrm{C}_{\text {org }}$ input to arable soils estimated by our method was slightly higher (3.7 $\mathrm{Mg} \mathrm{ha}^{-1} \mathrm{yr}^{-1}$ ) than estimated for Swedish arable soils: Andren et al. (2008) estimated $\mathrm{C}_{\text {org }}$ inputs in a range of $3.3 \mathrm{Mg} \mathrm{C} \mathrm{C}_{\text {org }}$ $\mathrm{ha}^{-1} \mathrm{yr}^{-1}$ in the south of Sweden to $2.6 \mathrm{Mg} \mathrm{C}_{\mathrm{org}} \mathrm{ha}^{-1}$ $\mathrm{yr}^{-1}$ in the north. Considering the climate advantages for crop cultivation in Germany compared to Sweden, $\mathrm{C}_{\text {org }}$ inputs estimated in the present study were comprehensible. Across arable crops, we found that $\mathrm{C}_{\text {org }}$ input to soil was strongly driven by $\mathrm{NPP}_{\text {tot }}$, while neither input as organic fertilizer nor $\mathrm{C}_{\text {org }}$ export correlated with $\mathrm{C}_{\text {org }}$ input. Thus, in the context of increasing SOC stocks for climate change mitigation, maximizing $\mathrm{NPP}_{\text {tot }}$, e.g., by cover crop cultivation, has a considerable potential to increase $\mathrm{C}_{\text {org }}$ input to soils.

We found no difference between mean annual $\mathrm{C}_{\text {org }}$ input to arable soils (3.7 $\mathrm{Mg} \mathrm{C}_{\text {org }} \mathrm{ha}^{-1} \mathrm{yr}^{-1}$ ) and to grassland soils (3.7 $\mathrm{Mg} \mathrm{C}_{\mathrm{org}} \mathrm{ha}^{-1} \mathrm{yr}^{-1}$ ). This was surprising, since SOC stock measured in the top $0-30 \mathrm{~cm}$ layer on the sites evaluated here was on average 1.4 times higher in mineral soils under grassland ( $89 \pm 36 \mathrm{Mg} \mathrm{C}_{\mathrm{org}} \mathrm{ha}^{-1}$ ) than under arable use $\left(62 \pm 30 \mathrm{Mg} \mathrm{C}_{\text {org }}\right.$ ha $^{-1}$; for details see Jacobs et al. 2018). This difference was often explained by the reduced physical disturbance (tillage) of grassland soils which enhances SOC storage (Six et al. 2000) on the one hand and by higher $\mathrm{C}_{\text {org }}$ inputs to grassland soils (Hu et al. 2019) on the other hand. However, the type of $\mathrm{C}_{\text {org }}$ serving as $\mathrm{C}_{\text {org }}$ input varies considerably between the two land use systems. The $\mathrm{C}_{\text {org }}$ input to grassland soils was dominated by root-derived $\mathrm{C}_{\text {org }}$ and the proportion was on average 1.4 times higher in the grassland than in the arable soils. This is in line with Pausch and Kuzyakov (2018) who reported that annual crops allocate less $\mathrm{C}_{\text {org }}$ belowground (21\%) than grassland specimen (33\%). However, it needs to be noted that we used a fixed value for root-derived $\mathrm{C}_{\text {org }}$ in grasslands (see below). Root-derived $\mathrm{C}_{\text {org }}$ was reported to contribute more to SOC stabilization as shoot-derived $\mathrm{C}_{\text {org }}$ for various reasons including higher chemical recalcitrance, physical protection by aggregates (Rasse et al. 2005 and papers cited therein) and microbial C-use efficiency (Sokol and Bradford 2019). For example, Kätterer et al. (2011) reported a 2.3 times higher stabilization rate of roots compared with shoots in a Swedish long-term field experiment. Further, in our study, $\mathrm{C}_{\text {org }}$ input to soil via organic fertilizers (mainly animal manure) was 1.6 times higher on grassland than on arable sites. Manure was also reported to build up SOC at a higher rate than fresh aboveground harvest residues, e.g. straw, (Kätterer et al. 2011) since the labile $C_{\text {org }}$ fraction is preferentially decomposed and already lost during gut passage and storage of manure. Straw was found to have a retention rate of about $10 \%$ or less (Lemke et al. 2010), while manure often reached retention rates of up to $30 \%$ (Kätterer et al. 2011) with a global average of 12\% (Maillard and Angers 2014).

An adapted method for estimation of organic carbon inputs to soils in Central Europe

The $\mathrm{C}_{\text {org }}$ input estimation method we developed is a revised version of allocation coefficients previously published (Bolinder et al. 2007; Gan et al. 2009; Li et al. 1997) adapted to regional conditions. For arable sites, we used regional harvest indices and the latest findings on rhizodeposition (Pausch and Kuzyakov 2018). However, recent studies claim that appyling yield-dependent ratios of $\mathrm{NPP}_{\text {above }}$ to $\mathrm{NPP}_{\text {below }}$ in $\mathrm{C}_{\text {org }}$ input estimation methods might be an oversimplification.

Such findings were clear and reliable for grassland specimen for which several independent studies showed that $\mathrm{NPP}_{\text {below }}$ is not a function of $\mathrm{NPP}_{\text {above }}$ in managed grasslands (Ammann et al. 2009; Cong et al. 2019; Poeplau et al. 2018; Sochorová et al. 2016) and that the ratio of $\mathrm{NPP}_{\text {above }}$ to $\mathrm{NPP}_{\text {below }}$ can vary 
greatly upon management intensity and yield. Thus, the application of a yield-dependent ratio of $\mathrm{NPP}_{\text {above }}$ to $\mathrm{NPP}_{\text {below }}$ would most likely cause large errors for the estimation of $\mathrm{NPP}_{\text {below }}$ (Poeplau 2016). This was supported by a recent publication of TaghizadehToosi et al. (2020) who also claimed that using a fixed value for belowground $\mathrm{C}_{\text {org }}$ input in leys improved SOC model simulations for several long-term field experiments compared to the application of a fixed ratio of $\mathrm{NPP}_{\text {above }}$ to $\mathrm{NPP}_{\text {below }}$ for the estimation of belowground $\mathrm{C}_{\mathrm{org}}$ inputs. Thus, for grassland sites, we made a fundamental change regarding the conventional estimation of belowground $\mathrm{C}_{\text {org }}$ input based on a ratio of $\mathrm{NPP}_{\text {above }}$ to $\mathrm{NPP}_{\text {below: }}$ We adopted the assumption of a fixed value for $\mathrm{NPP}_{\text {below }}$ and made use of a large German dataset of a related study of Poeplau et al. (2018). Based on these results, we assumed a fixed average root-derived $\mathrm{C}_{\text {org }}$ input of $2.2 \mathrm{Mg} \mathrm{C}_{\text {org }} \mathrm{ha}^{-1} \mathrm{yr}^{-1}$. This value is supported by Ammann et al. (2009) who measured root $\mathrm{C}_{\text {org }}$ stocks of 2.3 and $2.1 \mathrm{Mg} \mathrm{C}_{\text {org }} \mathrm{ha}^{-1}$ in intensively and extensively managed Swiss grassland, respectively.

For arable crops, recent findings are less profound: It was shown in two Swiss and one British field trial that maize and wheat have a much stronger aboveground than belowground response to fertilization (Hirte et al. 2018; Taghizadeh-Toosi et al. 2016) and a fixed root- $\mathrm{C}_{\text {org }}$ input value was regarded more robust for wheat (Taghizadeh-Toosi et al. 2016). However, at this current point of research, it is impossible to deduce reliable values replacing conventional $\mathrm{C}_{\text {org }}$ allocation coefficients by fixed root- $\mathrm{C}_{\text {org }}$ input for arable crops. Such values are not available for the majority of crops but crop types differ strongly in physiology. Thus, we decided to stick to the conventional assumption well proven by Bolinder et al. (2007) and provided regionally sound mean values of $\mathrm{NPP}_{\text {below }}$ (equal root- $\mathrm{C}_{\text {org }}$ input) as a starting point for future research. A SOC modeling study on German arable long-term monitoring sites using five different $\mathrm{C}_{\text {org }}$ input estimation methods (Riggers et al. 2019) supported this procedure: $\mathrm{C}_{\text {org }}$ input estimated by the here presented regional approach led to lower model errors than the original one of Bolinder et al. (2007). This is most likely because the latter summarized studies mainly from North America. To summarize, the $\mathrm{C}_{\text {org }}$ inputs we calculated for German arable and grassland soils can be regarded as most reliable.
The size and representativeness of the dataset used in this study to estimate management related $\mathrm{C}_{\text {org }}$ fluxes on German agricultural soils make it unique. Yield data are usually available on strongly aggregated scales or for certain crops only or they are gained from experimental sites that do not reflect commercial agriculture. Field-scale fertilization or residue management data are scarcely available at all. Here, we took the opportunity to comprehensively analyze a decade-long dataset obtained directly from about $1 \%$ of all German farmers through a questionnaire. Due to this unique dataset and the region-specific method we developed, the present study delivered the first robust estimates of $\mathrm{C}$-assimilation $\left(\mathrm{NPP}_{\text {tot }}\right)$ and $\mathrm{C}_{\text {org }}$ inputs and exports from German agricultural soils. Anyway, results are subject to two sources of uncertainty: one related to the dataset as such and the other related to assumptions used in the method. We hold that the priority for improvement of the method is to continue with crop- and site-specific quantification of root biomass in arable land and grasslands, as critical component of total plant-derived $\mathrm{C}_{\text {org }}$ input to soils.

\section{Conclusions}

Our study revealed that maximizing plant productivity, measured as NPP, has the greatest potential to maximize $\mathrm{C}_{\text {org }}$ inputs to soil and thus SOC stocks in agriculture. Any decrease in plant productivity, e.g. due to climate change induced droughts, threatens current SOC stocks. Surprisingly, total $\mathrm{C}_{\text {org }}$ inputs did not vary between grasslands and croplands, suggesting that large differences in SOC stocks usually observed between both land use types cannot be explained by differences in total $\mathrm{C}_{\text {org }}$ inputs. Quality and allocation of $\mathrm{C}_{\text {org }}$ input matter and point toward a pivotal role of roots for building SOC. A more profound understanding of the stabilization rates and pathways of various $\mathrm{C}_{\text {org }}$ input sources is thus necessary. We recommend using the method and data presented here for Central European agricultural soils as it complies the up-todate data sources available for this region. Yet, more field studies are needed to further improve $\mathrm{C}_{\text {org }}$ input estimates. For example, the role of different pedoclimatic regions as well as cultivars on allocation coefficients and $\mathrm{C}_{\text {org }}$ input estimates are widely neglected to date. The latter might be especially relevant for comparisons between organic and 
conventional farms, since organic agriculture uses with different cultivars. The role of breeding on allocation coefficients and, thus, root derived $\mathrm{C}_{\text {org }}$ input is poorly understood. The $\mathrm{C}_{\text {org }}$ input to soil is a large C-flux that is directly controlled by agricultural management. All efforts to maintain or increase SOC stocks can only be successful when we understand the effects of agricultural management of this flux in detail.

Acknowledgements This study was funded by the German Federal Ministry of Food and Agriculture in the framework of the German Agricultural Soil Inventory. We thank the field and laboratory teams of the German Agricultural Soil Inventory for their thorough and persistent work. Special thanks also to all farmers taking part within the Agricultural Soil Inventory.

Open Access This article is licensed under a Creative Commons Attribution 4.0 International License, which permits use, sharing, adaptation, distribution and reproduction in any medium or format, as long as you give appropriate credit to the original author(s) and the source, provide a link to the Creative Commons licence, and indicate if changes were made. The images or other third party material in this article are included in the article's Creative Commons licence, unless indicated otherwise in a credit line to the material. If material is not included in the article's Creative Commons licence and your intended use is not permitted by statutory regulation or exceeds the permitted use, you will need to obtain permission directly from the copyright holder. To view a copy of this licence, visit http://creativecommons.org/licenses/by/4.0/.

Funding Open Access funding provided by Projekt DEAL.

\section{References}

Ammann C, Spirig C, Leifeld J, Neftel A (2009) Assessment of the nitrogen and carbon budget of two managed temperate grassland fields. Agric Ecosyst Environ 133:150-162

Amon B, Kryvoruchko V, Amon T, Zechmeister-Boltenstern S (2006) Methane, nitrous oxide and ammonia emissions during storage and after application of dairy cattle slurry and influence of slurry treatment. Agric Ecosyst Environ 112:153-162

Andren O, Katterer T, Karlsson T, Eriksson J (2008) Soil C balances in Swedish agricultural soils 1990-2004, with preliminary projections. Nutr Cycl Agroecosyst 81:129-144. https://doi.org/10.1007/s10705-008-9177-z

Anonymous (2017) Düngeverordnung (DüV). https://www. gesetze-im-internet.de/d_v_2017/D\%C3\%BCV.pdf. Accessed 01 Oct 2019

Aschmann V, Effenberger M, Graf J, Halama M, Keymer U, Strobl M, Winkler J (2013) Bayernplan-Einsatz von Biogas zum Ersatz von Gaskraftwerken. Bayearsische Landesanstalt für Landwirtschaft (ed), Freising-
Weihenstephan. https://www.lfl.bayern.de/mam/cms07/ ipz/dateien/bayernplan_einsatz_von_biogas_zum_ersatz_ von_gaskraftwerken_ag1.pdf. Accessed 29 March 2018

Baldauf S, Bergmeister S (2006) Abbauverhalten von ausgewählten organischen Schadstoffen in Klärschlammkomposten bei veränderten Rotteparametern. Diploma, Höhere Technische Bundeslehr- und Versuchsanstalt Dornbirn

Bayrische Landesanstalt für Landwirtschaft (LfL) (2011) Integrierter Pflanzenbau-Zwischenfruchtanbau. https://www. lfl.bayern.de/mam/cms07/publikationen/daten/ informationen/p_28819.pdf. Accessed 18 Dec 2017

BIOS Bioenergies GmbH (2018) Biomass. http://www.ieabcc. nl/database/biomass.php. Accessed 29 March 2018

Bolinder MA, Janzen HH, Gregorich EG, Angers DA, VandenBygaart AJ (2007) An approach for estimating net primary productivity and annual carbon inputs to soil for common agricultural crops in Canada. Agric Ecosyst Environ 118:29-42. https://doi.org/10.1016/j.agee.2006. 05.013

Bolinder MA, Katterer T, Poeplau C, Borjesson G, Parent LE (2015) Net primary productivity and below-ground crop residue inputs for root crops: potato (Solanum tuberosum L.) and sugar beet (Beta vulgaris L.). Can J Soil Sci 95:87-93. https://doi.org/10.4141/cjss-2014-091

Brosowski A, Thrän D, Mantau U, Mahro B, Erdmann G, Adler P, Stinner W, Reinhold G, Hering T, Blanke C (2016) A review of biomass potential and current utilisation: status quo for 93 biogenic wastes and residues in Germany. Biomass Bioenergy 95:257-272. https://doi.org/10.1016/j. biombioe.2016.10.017

Chenu C, Angers DA, Barré P, Derrien D, Arrouays D, Balesdent J (2019) Increasing organic stocks in agricultural soils: knowledge gaps and potential innovations. Soil Tillage Res 188:41-52

Christensen BT, Rasmussen J, Eriksen J, Hansen EM (2009) Soil carbon storage and yields of spring barley following grass leys of different age. Eur J Agron 31:29-35. https:// doi.org/10.1016/j.eja.2009.02.004

Cong WF, Christensen BT, Eriksen J (2019) Soil nutrient levels define herbage yield but not root biomass in a multispecies grass-legume ley. Agric Ecosyst Environ 276:47-54. https://doi.org/10.1016/j.agee.2019.02.014

Deutscher Wetterdienst (2020) regional_averages_rr_year. $\mathrm{ftp}: / /$ opendata.dwd.de/climate_environment/CDC/regional_ averages_DE/annual/precipitation/. Accessed 07 May 2020

Feller C, Fink M, Laber H, Maync A, Paschold PJ, Scharpf HC, Schlaghecken J, Strohmeyer K, Weier U, Ziegler J (2011) Düngung im Freilandgemüsebau. Schriftenreihe des Institutes für Gemüse-und Zierpflanzenbau Großbeeren und Erfurt http://www.igzev.de/publikationen/IGZ_Duengung_ im_Freilandgemuesebau.pdf. Accessed 26 April 2018

Franko U, Kolbe H, Thiel E, Liess E (2011) Multi-site validation of a soil organic matter model for arable fields based on generally available input data. Geoderma 166:119-134. https://doi.org/10.1016/j.geoderma.2011.07.019

Freibauer A, Rounsevell MDA, Smith P, Verhagen J (2004) Carbon sequestration in the agricultural soils of Europe. Geoderma 122:1-23

Gan YT, Campbell CA, Janzen HH, Lemke RL, Basnyat P, McDonald CL (2009) Carbon input to soil from oilseed and 
pulse crops on the Canadian prairies. Agric Ecosyst Environ 132:290-297. https://doi.org/10.1016/j.agee.2009.04. 014

Gill RA, Jackson RB (2000) Global patterns of root turnover for terrestrial ecosystems. The New Phytologist 147:13-31

Graf T, Reinhold G, Biertümpfel A, Zorn W (2005) Leitlinie zur effizienten und umweltverträglichen Erzeugung von Faserhanf. http://www.tll.de/www/daten/publikationen/ leitlinien/hanf0805.pdf. Accessed 13 Jan 2020

Griffin T, He Z, Honeycutt C (2005) Manure composition affects net transformation of nitrogen from dairy manures. Plant Soil 273:29-38

Haberl H, Erb KH, Krausmann F, Gaube V, Bondeau A, Plutzar C, Gingrich S, Lucht W, Fischer-Kowalski M (2007) Quantifying and mapping the human appropriation of net primary production in earth's terrestrial ecosystems. Proc Natl Acad Sci 104:12942-12947. https://doi.org/10.1073/ pnas.0704243104

Hirte J, Leifeld J, Abiven S, Oberholzer H-R, Mayer J (2018) Below ground carbon inputs to soil via root biomass and rhizodeposition of field-grown maize and wheat at harvest are independent of net primary productivity. Agric Ecosyst Environ 265:556-566

Hu T, Taghizadeh-Toosi A, Olesen JE, Jensen M, Sørensen P, Christensen BT (2019) Converting temperate long-term arable land into semi-natural grassland: decadal-scale changes in topsoil C, N, 13C and $15 \mathrm{~N}$ contents. Eur J Soil Sci 70:350-360

Jacobs A, Flessa H, Don A, Heidkamp A, Prietz R, Dechow R, Gensior A, Poeplau C, Riggers C, Schneider F, Tiemeyer B, Vos C, Wittnebel M, Müller T, Säurich A, FahrionNitschke A, Gebbert S, Hopfstock R, Jaconi A, Kolata H, Lorbeer M, Schröder J, Laggner A, Weiser C, Freibauer F (2018) Landwirtschaftlich genutzte Böden in Deutschland-Ergebnisse der Bodenzustandserhebung. Thünen Report 64 64. https://www.thuenen.de/media/institute/ak/ Allgemein/news/Thuenen_Report_64_final.pdf. Accessed 13 Janurary 2020

Johnston AE, Poulton PR, Coleman K (2009) Soil organic matter: its importance in sustainable agriculture and carbon dioxide fluxes. Adv Agron 101:1-57

Jordan SN, Mullen GJ, Murphy MC (2008) Composition variability of spent mushroom compost in Ireland. Bioresour Technol 99:411-418. https://doi.org/10.1016/j.biortech. 2006.12.012

Kätterer T, Bolinder MA, Andren O, Kirchmann H, Menichetti L (2011) Roots contribute more to refractory soil organic matter than above-ground crop residues, as revealed by a long-term field experiment. Agric Ecosyst Environ 141:184-192. https://doi.org/10.1016/j.agee.2011.02.029

Kätterer T, Bolinder M, Berglund K, Kirchmann H (2012) Strategies for carbon sequestration in agricultural soils in northern Europe. Acta Agric Scand Sect A Anim Sci 62:181-198

Keel SG, Leifeld J, Mayer J, Taghizadeh-Toosi A, Olesen JE (2017) Large uncertainty in soil carbon modelling related to method of calculation of plant carbon input in agricultural systems. Eur J Soil Sci 68:953-963

Kuratorium für Technik und Bauwesen in der Landwirtschaft (KTBL) (2009) Faustzahlen für die Landwirtschaft. Darmstadt
Landwirtschaftskammer Niedersachsen (2007) Die Düngeverordnung und ihre Umsetzung im Gemüsebau. https://www.lwk-niedersachsen.de/download.cfm/file/5259. html. Accessed 06 June 2017

Landwirtschaftskammer Niedersachsen (2014) Nährstoffgehalte im Haupt- und Nebenerntegut. https://www.lwkniedersachsen.de/download.cfm/file/26388.html. Accessed 06 June 2017

Landwirtschaftskammer Nordrhein-Westfalen (2015) Zwischenfruchtanbau-Arten und Mischungen. https://www.landwirts chaftskammer.de/Landwirtschaft/ackerbau/zwischenfruechte /zwischenfruchtanbau-pdf.pdf. Accessed 18 Dec 2017

Laufer D, Nielsen O, Wilting P, Koch H-J, Märländer B (2016) Yield and nitrogen use efficiency of fodder and sugar beet (Beta vulgaris L.) in contrasting environments of northwestern Europe. Eur J Agron 73:124-132

Lemke R, VandenBygaart A, Campbell C, Lafond G, Grant B (2010) Crop residue removal and fertilizer N: effects on soil organic carbon in a long-term crop rotation experiment on a Udic Boroll. Agric Ecosyst Environ 135:42-51

Li CS, Frolking S, Crocker GJ, Grace PR, Klir J, Korchens M, Poulton PR (1997) Simulating trends in soil organic carbon in long-term experiments using the DNDC model. Geoderma 81:45-60. https://doi.org/10.1016/s00167061(97)00080-3

Maillard É, Angers DA (2014) Animal manure application and soil organic carbon stocks: a meta-analysis. Glob Chang Biol 20:666-679. https://doi.org/10.1111/gcb.12438

Minasny B, Malone BP, McBratney AB, Angers DA, Arrouays D, Chambers A, Chaplot V, Chen Z-S, Cheng K, Das BS (2017) Soil carbon 4 per mille. Geoderma 292:59-86

Möller K, Schultheiß U (2015) Chemical characterization of commercial organic fertilizers. Arch Agron Soil Sci 61:989-1012. https://doi.org/10.1080/03650340.2014. 978763

Morvan T, Nicolardot B (2009) Role of organic fractions on C decomposition and $\mathrm{N}$ mineralization of animal wastes in soil. Biol Fertil Soils 45:477-486

Nodar R, Acea MJ, Carballas T (1992) Poulty slurry microbial population - Composition and evolution during storage. Bioresour Technol 40:29-34. https://doi.org/10.1016/ 0960-8524(92)90115-e

Nordin A (1994) Chemical elemental characteristics of biomass fuels. Biomass Bioenergy 6:339-347

Obernberger I, Brunner T, Bärnthaler G (2006) Chemical properties of solid biofuels-significance and impact. Biomass Bioenergy 30:973-982

Pausch J, Kuzyakov Y (2018) Carbon input by roots into the soil: Quantification of rhizodeposition from root to ecosystem scale. Glob Chang Biol 24:1-12. https://doi.org/ $10.1111 /$ gcb. 13850

Poeplau C (2016) Estimating root: shoot ratio and soil carbon inputs in temperate grasslands with the RothC model. Plant Soil 407:293-305. https://doi.org/10.1007/s11104-0163017-8

Poeplau C, Zopf D, Greiner B, Geerts R, Korvaar H, Thumm U, Don A, Heidkamp A, Flessa H (2018) Why does mineral fertilization increase soil carbon stocks in temperate grasslands? Agric Ecosyst Environ 265:144-155 
Quiroga G, Castrillón L, Fernández-Nava Y, Marañón E (2010) Physico-chemical analysis and calorific values of poultry manure. Waste Manag 30:880-884

Rasse DP, Rumpel C, Dignac MF (2005) Is soil carbon mostly root carbon? Mechanisms for a specific stabilisation. Plant Soil 269:341-356

Reinhold G, Mumdey A (2012) Inhaltsstoffe von Biogassubstraten und Gärresten (Datenblätter). http://www.tll.de/ www/daten/publikationen/merkblaetter/bwx31012.pdf. Accessed 02 Oct 2019

Riggers C, Poeplau C, Don A, Bamminger C, Hoper H, Dechow R (2019) Multi-model ensemble improved the prediction of trends in soil organic carbon stocks in German croplands. Geoderma 345:17-30. https://doi.org/10.1016/j. geoderma.2019.03.014

Rösemann C, Haenel H-D, Dämmgen U, Freibauer A, Döring U, Wulf S, Euich-Menden B, Döhler H, Schreiner C, Osterburg B (2017) Calculations of gaseous and particulate emissions from German agriculture 1990-2015. Report on methods and data (RMD) submission 2017. Thünen Report 46. https://doi.org/10.3220/rep1490877117000

Rynk R, van de Kamp M, Wilson GB, Singley ME, Richard TL, Gouin FR, Laliberty L, Kay D, Murphy DW, Hoitink HAJ, Brinton WF (1992) On-farm composting handbook. Northeast Regional Agricultural Engineering Service, Ithaca

Schulze ED, Luyssaert S, Ciais P, Freibauer A, Janssens IA, Soussana JF, Smith P, Grace J, Levin I, Thiruchittampalam B, Heimann M, Dolman AJ, Valentini R, Bousquet P, Peylin P, Peters W, Rodenbeck C, Etiope G, Vuichard N, Wattenbach M, Nabuurs GJ, Poussi Z, Nieschulze J, Gash JH, CarboEurope T (2009) Importance of methane and nitrous oxide for Europe's terrestrial greenhouse-gas balance. Nat Geosci 2:842-850. https://doi.org/10.1038/ ngeo686

Six J, Paustian K, Elliot ET, Combrink C (2000) Soil structure and organic matter: I. Distribution of aggre-gate-size classes and aggregate-associated carbon. Soil Sci Soc Am J 64:681-689. https://doi.org/10.2136/sssaj2000.642681x

Sochorová L, Jansa J, Verbruggen E, Hejcman M, Schellberg J, Kiers ET, Johnson Collins N (2016) Long-term agricultural management maximizing hay production can significantly reduce belowground $\mathrm{C}$ storage. Agric Ecosyst Environ 220:104-114
Sokol NW, Bradford MA (2019) Microbial formation of stable soil carbon is more efficient from belowground than aboveground input. Nat Geosci 12:46

Statistisches Bundesamt (Destatis) (2003-2018) Fachserie 3.2.1 Land- und Forstwirtschaft, Fischerei: Wachstum und Ernte. https://www.destatis.de/DE/Home/_inhalt.html. Accessed 02 Oct 2019

Taghizadeh-Toosi A, Christensen BT, Glendining M, Olesen JE (2016) Consolidating soil carbon turnover models by improved estimates of belowground carbon input. Sci Rep 6:32568

Taghizadeh-Toosi A, Cong W-F, Eriksen J, Mayer J, Olesen JE, Keel SG, Glendining M, Kätterer T, Christensen BT (2020) Visiting dark sides of model simulation of carbon stocks in European temperate agricultural soils: allometric function and model initialization. Plant Soil 450:255-272. https:// doi.org/10.1007/s11104-020-04500-9

Technologie- und Förderzentrum im Kompetenzzentrum für Nachwachsende Rohstoffe (2007) Anbauhinweise Buchweizen. http://www.tfz.bayern.de/mam/cms08/rohstoff pflanzen/dateien/pfl_anbau_buchweizen.pdf. Accessed 13 Jan 2020

Vassilev SV, Baxter D, Andersen LK, Vassileva CG (2010) An overview of the chemical composition of biomass. Fuel 89:913-933

Verband der Landwirtschaftskammern (n.d.) Zwischenfrüchte für Futternutzung und Gründüngung. Hinweise zur Artenwahl, Nutzungsmöglichkeiten und Anbauverfahren. https://www.landwirtschaftskammer.de/riswick/pdf/fbzwischenfruechte-2012.pdf. Accessed 02 Oct 2019

Wendland M, Diepolder M, Offenberger K, Raschbacher S (2018) Leitfaden für die Düngung von Acker- und Grünland-Gelbes Heft. https://www.lfl.bayern.de/mam/cms07/ publikationen/daten/informationen/leitfaden-duengungacker-gruenland_gelbes-heft_lfl-information.pdf. Accessed 04 May 2020

Zorn W, Heß H, Albert E, Kolbe H, Kerschberger M, Franke G (2007) Düngung in Thüringen 2007 nach "Guter fachlicher Praxis". Landwirtschaft und Landschaftspflege in Thüringen 7. http://www.tll.de/www/daten/pflanzenproduktion/ duengung/dung0108.pdf. Accessed 01 Oct 2019

Publisher's Note Springer Nature remains neutral with regard to jurisdictional claims in published maps and institutional affiliations. 